\title{
LAS FUENTES DE HESIODO Y LA COMPOSICION DE SUS POEMAS
}

\begin{abstract}
Various elements of Hesiod's poems (cosmogony, theogony, series of proverbial maxims, etc.) originate in Eastern Literature, and this assertion is today accepted by all. The author of this paper thinks that the knowledge of those models could be profitable in order to study how Hesiod has modified and combined them to produce his great poems. He also believes that Hesiod is dependent on Greek poetry inspired on those models and on other ones more properly Greek. But the result of his re-elaboration of the pre-Hesiodic Greek poetry is two poems very new and original regarding their composition and ideas.
\end{abstract}

\section{Algunos precedentes}

Las fuentes y los modelos de Homero, es decir, la épica micénica, sólo en alguna medida podemos reconstruirlos o imaginar cómo eran a partir de los propios poemas de Homero, aunque puedan añadirse datos precedentes de la épica comparada. En cambio, en el caso de Hesíodo, tenemos testigos independientes: mitos y géneros orientales -mesopotámicos, hurritas, egipcios, etc.- que hoy se está de acuerdo en que de una manera $u$ otra influenciaron la poesía hesiódica. Podemos, por tanto, presumir que en el caso de ésta será más hacedero establecer el tratamiento que el poeta daba a sus materiales, lo que hay de original en su composición, la intención que subyace a la misma. Y más si contamos con que tenía delante de sí, al tiempo, el modelo de Homero (aunque esto a veces se discute, véase a continuación). Pero la verdad es que el estudio de la composición hesiódica en relación con sus materiales y antecedentes apenas ha sido abordado, que sepamos. Vamos a hacer aquí el intento de avanzar por este terreno en la medida de 10 posible.

Claro está que el concepto de «fuentes» debe ser precisado en este caso cuidadosamente y lo mismo el de «modelos». Para empezar, hay 
que distinguir entre los mitos y sus versiones literarias. El mito cosmugónico y el mito de la sucesión en la Teogonía están emparentados, como se sabe, con mitos orientales: hurritas (El reinado de los Cielos, Hedammu, El canto de Ullikummi), babilonios (Enuma Elish o Poema de la Creación) y fenicios (las noticias de Filón de Biblos y ciertos textos de Ras Shamra), sobre todo.

Pero el problema es el de si estos mitos llegaron a Hesíodo por haberse difundido previamente en Grecia o bien directamente de uno $u$ otro modo. En este último caso, puede haber influido una tradición oral o una tradición literaria. Y, todavía, para esta tradición puede haber un intermedio griego, también literario. Hay muchas razones a favor de esta última hipótesis: entre otras, que pese a las semejanzas hay grandes diferencias entre la versión hesiódica y las orientales; y que hay huella en Grecia de un tratamiento literario prehesiódico de estos temas.

Ciertamente, sean cualesquiera las soluciones que se den a los problemas de cronología y de los textos intermedios, la proximidad de Hesíodo a las tradiciones recogidas en esos mitos y poemas es mucho mayor de la que puede haber, por ejemplo, entre el Poema de Gilgamés y los poemas homéricos, pese a que algunos de los ecos de aquel que se propone que existen en Homero, pueden ser ciertos ${ }^{1}$. Y, sin descartar la presencia en Hesíodo de tradiciones que previamente habían arraigado en Grecia o le habían llegado a él por vía oral en Cima o en Beocia, parece preferible la hipótesis de que el influjo oriental principal se ha ejercido, sin duda mediatamente, a través de textos literarios. Pues la difusión de las doctrinas cosmogónicas y sobre la sucesión de los dioses, se realiza en Asia por medio de poemas recitados en el contexto de ceremonias de culto. Así en el caso del Enuma Elish (recitado en la fiesta de Akitu o Año Nuevo) y en otros más ${ }^{2}$. En Grecia misma estaban asociadas a la literatura religiosa de adivinos y profetas (Orfeo, Museo, Aristeas, Abaris, Epiménides, los órficos).

Sobre todo, es notable que en los poemas asiáticos a que nos referimos estén asociados, igual que en Grecia, un elemento cosmogónico y el mito de la sucesión de los dioses; hay además elementos épicos y genealógicos, ciertamente más desarrollados en Grecia. La coincidencia no puede ser casual. $Y$ se añade algo muy importante: también para otros elementos de los poemas hesiódicos existen precedentes en géneros literarios orientales. Se trata, como es bien sabido, de dos tipos

1 Cf. bibliografía en R. Adrados, Fernández-Galiano, Luis Gil y Lasso de la Vega, Introducción a Homero, 2." ed., Barcelona 1984, p. 74 ss. y en Jordi Cors i Meya, El viatge al món dels morts en l'Odissea, Barcelona 1984, p. 506 ss.

2 Cf. M. L. West, Hesiod. Theogony, Oxford University Press 1966, p. 2. 
diferentes de «máximas» o «preceptos»: aquellos agrupados en colecciones inorgánicas, de destinatario anónimo, desde la época sumeria a la neobabilonia; y aquellos que se presentan como impartidos por un padre a un hijo o bien como consejos dados por un visir a un rey o príncipe: es un género frecuente desde época sumeria y, en Egipto, desde el Imperio Medio ${ }^{3}$.

Nótese que son géneros muy difundidos fuera de Grecia. Las colecciones de proverbios "generales» están representadas por veinticuatro colecciones sumerias, algunas editadas por Gordon y Alster, otras en trance de ser editadas por Falkowitz ${ }^{4}$. Hay, además, textos babilonios editados primero por Ebeling y ahora por Lambert ${ }^{5} \mathrm{y}$ los Consejos de un pesimista, asirios ${ }^{6}$. Hay luego las colecciones «personales", que van de la época sumeria a la asiria. En Mesopotamia tenemos, con el tema de los consejos de un padre a un hijo (en contexto mítico o legendario casi siempre), las Instrucciones de suruppak (a su hijo Ziušudra, salvado del Diluvio; en torno al 2500 a. C.) ${ }^{7}$, los Consejos de Sabiduría (hacia 1500-1200) ${ }^{8}$, el escrito El escriba y su perverso hijo (no fechado) ${ }^{9}$. Consejos del padre (adoptivo) al hijo se dan también en dos series complejas en el Ahikar, de fecha asiria. Y hay que añadir un texto de Ras Shamra, los Consejos de subě-awìlum a su hijo. Más o menos paralelos son textos egipcios que comienzan por las Instrucciones de Ptahhotep (un visir de la V dinastía, c. 2500 a. C., a su hijo) y siguen con las de Merikare (c. 2100), Amenenket (c. 1900 a. C.), Ani, Amenemhotep y otras ${ }^{10}$. Nótese que con frecuencia se introduce el tema político: las instrucciones de Merikare son dadas a este rey, aunque sea por su padre.

También en Mesopotamia aparecen las instrucciones dadas al rey, como las que da Hesíodo a los reyes de Tespias. En la colección de Lambert hay, efectivamente (p. 110 ss.) unos Consejos a un Príncipe, de época babilonia, entre el 1000 y el 700 a. C. El tema del diálogo entre

3 Pues bien, uno y otro género han influido en Hesíodo, aunque en él no š hable de un padre y un hijo, sino de Hesíodo y su hermano Perses.

4 Cf. E. C. Gordon, «A new Look at the Wisdom of Sumer and Akkad», Bibl. Orientalis 17, 1960, pp. 122-152; W. H. P. Römer, «Fünf und zwanzig Jahre der Erforschung Sumerischer literarischer Texte», Bibl. Orientalis 31, 1974, pp. 207-222; Historia de la Fabula Greco-Latina, Madrid, Universidad Complutense, I, 1979, pp. 307 ss., 348 ss., y Falkowitz en La Fable, Entretiens sur l'Antiquité Classique XXX, Vandœuvres-Genève 1983, p. 1 ss.

5 Babylonian Wisdom Literature, Oxford 1960, p. 213 ss.

6 Lambert, p. 107.

7 Lambert, p. 92 ss.

8 Lambert, p. 96 ss.

9 Cf. West, ob. cit., p. 5.

10 Cf. West, ob. cit., p. 8 ss. 
un rey y un sabio aparece ya en narraciones sumerias como La joven y el viejo y Los tres boyeros de Adab. Estos temas se mantienen, por herencia mesopotámica, en la literatura fabulística india y en la griega (Vida de Esopo, Vida de Secundo, etc.) y pasan a las literaturas medievales "

$\mathrm{Y}$ existen todavía otros géneros que influyen en Hesíodo: el calendario agrícola de Trabajos y Días tiene precedentes sumerios y egipcios y también los tiene en Mesopotamia la sección de «Los días» en la misma obra ${ }^{12}$.

Dejando de lado, de momento, el problema de cómo estos géneros literarios o bien otros griegos derivados de ellos o influidos por ellos fueron conocidos por Hesíodo, de lo que no cabe duda es de que las dos obras esenciales de nuestro poeta no pueden explicarse sin ellos. Y no sólo en cuanto a detalles de su contenido, sino también en cuanto a su composición. La Teogonía es esencialmente la suma de dos procmios líricos de estructura ternaria y una epopeya cosmogónico-teogónica, centrada esta segunda parte en el mito de la sucesión. Sólo que en ella adquiere especial relevancia el mito divino, mediante relatos épicos colocados en determinados puntos; y también la poesía genealógica, que lleva el poema hasta el punto en que se menciona a los héroes nacidos de Zeus y mujeres humanas (si se descarta lo que sigue como un añadido). Esta épica divina y este elemento genealógico no faltan en los precedentes orientales, pero alcanzan aquí un desarrollo mucho mayor. En Grecia, para esbozar el tema, se han unido un género lírico griego y uno épico oriental. Veremos que con rasgos nuevos muy acusados.

Paralelamente, Trabajos y Días no es otra cosa que un proemio lírico seguido de series de preceptos o consejos: primero mediante varios mitos y una fábula, luego mediante series alternativas de consejos a Perses (también a los reyes) y consejos destinados a todos los oyentes del poeta. Todo esto es enlazado de algún modo con un calendario agrícola, con consejos sobre la navegación a todas luces complementarios del mismo, con otra serie de máximas y con el hemerologio de los días faustos e infaustos.

En ambos casos un género griego, el himno que sirve de proemio, ha sido puesto en cabeza del género oriental: la épica cosmogónica, teogónica y divina en general (Teogonía) y las series de preceptos (Tra-

11 Como indico en mi Historia... I, p. 680 ss. y en «Elementos cínicos en las Vidas de Esopo y Secundo y en el Diálogo de Alejandro y los gimnosofistas», Homenaje al P. Elorduy, Bilbao 1978, pp. 309-329.

12 Cf. P. Walcot, Hesiod and the Near East, Cardiff 1966, pp. 93 ss., 101 ss. Esta obra es importante para los demás precedentes a que hemos aludido. 
bajos y Dias). En ambos casos esta segunda parte ha sido ampliada, sobre todo en su final, mediante la adición de géneros, orientales o griegos, más o menos emparentados. $\mathrm{Y}$ en ambos falta cualquier cierre final. Así el proemio a-b-c (duplicado en Teogonía) anticipa mediante su elemento $b$ el poema épico o didáctico que sigue. Pero el total del proemio constituye un elemento $a$ frente al $b$ constituido por su continuación: falta un elemento $c$ de cierre. En cambio, es analizable en elementos subordinados, de los que hablaremos.

Se ha creado así un modelo de composición sumamente importante en la literatura griega, baste pensar en Parménides o Heráclito o bien en los escritores hipocráticos, si bien aquí existe el elemento $c$ del cicrre ${ }^{13}$. Hesíodo ha realizado una síntesis de varios géneros para crear un tipo de poesía, que llamamos por comodidad didáctica, que suministrará el modelo para casi toda la literatura filosófica y científica. En realidad, su tendencia a la síntesis había sido destacada ya antes cn otro aspecto, el del pensamiento ${ }^{14}$.

Resulta notable que, siendo esto así, la investigación de la composición de Hesíodo no haya tenido en cuenta hasta ahora, parece, estos puntos de vista. En realidad el estudio de su lengua, estilo y composición se ha centrado casi siempre en problemas como el de la oralidad, el de la relación cronológica con Homero y, sobre todo, el de si su texto contiene interpolaciones recientes. En la medida en que esto no es así, se ha insistido siempre, más que nada, en la "debilidad lógica" de la organización de los poemas ${ }^{15}$. Esta debilidad lógica se ha intentado a veces salvarla bien proponiendo la existencia de interpolaciones, bien acudiendo a nuevas interpretaciones de la composición en la línea de los unitarios en el estudio de Homero ${ }^{16}$. Aunque hay que reconocer que en Hesíodo la crítica analítica es la que predomina.

En el problema de la oralidad de los poemas de Hesíodo están centrados estudios como el de G. P. Edwards ${ }^{17}$ sobre la lengua, con una conclusión positiva, o el de William W. Minton ${ }^{18}$ sobre las fórmulas,

13 Cf. Francisco R. Adrados, “Los géneros literarios griegos», Revista 1616 (Madrid) 1, 1978, p. 163 ss. También Alberto Bernabé, «Los filósofos presocráticos como autores literarios», EMERITA 47, 1979, pp. 357-394 y Dolores Lara, Estudio sobre in composición de algunos tratados hipocráticos, tesis doctoral inédita, Madrid 1984.

14 Cf. Friedrich Solmsen, Hesiod and Aeschylus, Ithaca, New York 1949, p. 68.

15 Cf. por ej. W. J. Verdenius, «Aufbau und Absicht der Ergan, en Hésiode et son influence, Entretiens de la Fondation Hardt 7, Ginebra 1960, p. 119.

16 Así por ej. Suzanne Said, "Les combats de Zeus et le problème des interpolations dans la Théogonie d'Hésiode», REG 90, 1977, pp. 183-210.

17 The Language of Hesiod in its traditional Context, Oxford, Blackwell, 1971.

18 «The frequency and structuring of traditional formulas in Hesiod's Theogonv, HStCPh 79, 1975, pp. 25-48. 
también en definitiva positivo. Pienso que una buena solución es la de West ${ }^{19}$ que distingue entre "estilo oral", ejecución oral y eventual escritura (por el autor o a su dictado), que puede sufrir revisiones y recitarse otra vez. Este problema se complica con el de la cronología: aunque habitualmente se considera que nuestro poeta es posterior a Homero, existe la teoría de que es anterior a la mayor parte de la Odisea, cf. sobre todo a este respecto el libro de Inez Sellschopp ${ }^{20}$. Pero hay argumentaciones positivas en contra, así la de Heinz Neitzel ${ }^{21}$ y, sobre todo, el detallado estudio lingüístico, hecho con ayuda de ordenador, de Richard Janko ${ }^{22}$, que establece un orden Iliada-Odisea-Teogonía-Trabajos y Días pero que comete, en nuestra opinión, el error de no admitir la presencia en Hesíodo de tradiciones no homéricas, véase más adelante. Por lo demás, ya Solmsen ${ }^{23}$ estableció el conocimiento por parte de Hesíodo de los pasajes cosmogónicos de Ilíada, véase más adelante. Todo esto es importante, veremos que en lo relativo a la composición de Teogonía hay que contar con el modelo homérico. Pero hemos de añadir también datos sobre la existencia de otros modelos griegos tradicionales, influidos a su vez por la tradición oriental.

Como paso previo antes de este estudio, a su vez enlazado con el de la composición hesiódica, hay que insistir en el problema de las reales o supuestas interpolaciones en las obras que nos han llegado. Puede verse un resumen de la historia de la cuestión en el libro de Edwards antes mencionado (p. 4 ss.), al cual hay que añadir, entre otras cosas, un estudio reciente de Solmsen ${ }^{24}$, en el cual trata de distinguir entre adiciones y revisiones del propio Hesíodo y expansiones y añadidos de los rapsodos.

Por lo que respecta a la Teogonía hay que decir que en general se está de vuelta respecto a la terrible reducción del texto que proponían Jacoby y Schwenn (442 y 448 líneas respectivamente de las 1022 transmitidas). Por unos u otros motivos se hacen sospechosos pasajes que, en genealogías o catálogos, parecen romper la secuencia cronológica o lógica, otros que interrumpen el relato genealógico mediante narraciones épicas (Titanomaquia, episodio de Tifeo) o himnos (el dirigido a

19 M. L. West, «Is the 'Works and Days' an oral poem?», en I poemi epici rapsodici non homerici e la tradizione orale, Padova, Antenore, 1981, pp. 53-67.

20 Stylistische Untersuchungen zu Hesiod, Darmstadt 1967.

21 "Zum zeitlichen Verhältnis von Theogonie (80-93) und Odyssee (8.166-177)», Philologus 121, 1977, pp. 24-44. Así también un trabajo de O. Tsagarakis, que aparecerá próximamente en esta revista.

22 Homer, Hesiod and the Hymns, Cambridge 1982.

23 Ob. cit., p. 10 ss.

24 "The earliest stages in the History of Hesiod's Text», HStCPh 86, 1982, pp. 1-33. 
Hécate) o descripciones (la del Tártaro); finalmente, la parte final, más allá del relato de la descendencia de Zeus y sus hermanos. No entro en el detalle de las posiciones de los diversos autores: la más conservadora es la de West, que casi sólo atetiza el pasaje sobre Cíclopes y Cienbrazos (139-153), hijos de Urano que no parecen apoyar la rebelión de los Titanes y más tarde ayudarán a Zeus contra éstos, y el final. $\mathrm{Y}$ no faltan el unitarismo estricto, por ejemplo en el caso de Hans Schwabl ${ }^{25}$.

Naturalmente, no es éste el lugar de entrar a fondo en el tema, sólo el de señalar algunos puntos significativos. Que puede haber pequeñas alteraciones o interpolaciones, no puede excluirse; y es prácticamente seguro que el final de la Teogonía, seguramente a partir de 955, nacimiento de Heracles ${ }^{26}$, es un añadido: con los hijos de Zeus culmina su gloria y todo aquello que está anunciado en el proemio. Pero hay que darse cuenta de que el resto de las atétesis está en función, en definitiva, de prejuicios de los distintos autores sobre la idea central de la Teogonía, sobre lo que es una composición "lógica» y coherente, etcétera: ideas de sobra acreditadas después de haber sido previamente aplicadas al análisis homérico.

Que se atetice el pasaje sobre Cíclopes y Cienbrazos con el argumento de que no forman partido con los Titanes, es inconveniente: aparecen luego en la obra, de modo que es justo que se hable de su nacimiento. Si se opina que algunos hijos de la Noche deben atetizarse porque no tienen "carácter sombrío", se olvida que la Noche tiene también otras relaciones (con el lejano Occidente, el amor, etc.) ${ }^{27}$. Las desviaciones por ramas laterales; las vueltas hacia atrás, etc. en genealogías y catálogos tienen que ver a su vez con el deseo de suministrar descripciones completas del mundo divino y natural, si es que cabe esta división. Cierto que los lazos de unión son a veces flojos, se utilizan para ello simples ecos verbales cuando no yuxtaposiciones.

Ese intento de lograr descripciones completas del mundo explica episodios como el del Tártaro; el nacimiento de Afrodita, el himno a Hécate se explican igual. Por eso, argüir que la Teogonía desprovista de las supuestas interpolaciones queda más centrada en Zeus ${ }^{28}$ es atribuir al poeta unos propósitos y un ideal de composición que sin duda le eran ajenos: esto al menos es lo que se piensa hoy generalmente respecto a la Ilíada, donde también se propusieron diversas atétesis

25 Hesiods Theogonie. Eine unitarische Analyse, Viena, SBAW, 1966.

26 Cf. Mark D. Northrup, "Where did the Theogony end?», SO 58, 1983, pp. 7-13.

27 Cf. West, ob. cit., p. 15.

28 Así Kirk, lug. cit., p. 84. 
con la finalidad de reducirla a un argumento en línea recta, concentrado, sin excursos.

No es éste el modo de proceder para interpretar la composición de Hesíodo. Esta composición está en relación con su intención y ésta es, claramente, una descripción exhaustiva, aunque el poeta tenga que perderse en ramas colaterales, añadir excursos, etc. Ciertamente, existe el tema de Zeus, que culmina en la Titanomaquia y el episodio de Tifeo, extrañamente atetizados a veces y cuya autenticidad defendió muy bien Mme. Said en un trabajo citado más arriba. Lo importante es ver cómo la línea principal Urano-Crono-Zeus sale a flote una y otra vez en medio del material circundante, cómo hay constantes anticipos y puestas de relieve de esta línea central, que a veces parece perdida. Este panorama recuerda muy de cerca la composición de la Ilíada y nos aleja de las cosmogonías orientales, más en línea recta: es evidentemente un elemento helénico y hesiódico.

Algo parecido habría que decir de los Trabajos y Días, para los que Verdenius, en un trabajo ya citado ${ }^{20}$, así como West en su edición ${ }^{30}$, admiten francamente que no hay que postular una composición rigurosa y sistemática. Acudir a las interpolaciones no ayuda gran cosa; incluso en el pasaje sobre "Los días", el más sospechoso, puede haber argumentos para defender la autenticidad ${ }^{31}$. Puestos a atetizar, habría que atetizarlo casi todo. Por el contrario, lo que hay que hacer es estudiar cómo mitos y fábulas han entrado en sistema con elementos originalmente tan dispares como un himno a las Musas, consejos con varios destinatarios, un calendario agrícola seguido de instrucciones para la navegación, una nueva serie de máximas, la relación de "Los días». En un conjunto de este tipo, en el que el hilo unificador ya sale a luz, ya se pierde, no es imposible que se hayan introducido interpolaciones. Pero lo fundamental no es esto, sino el principio mismo según el cual géneros dispares se han asociado en la forma en que Hesíodo los asocia.

En suma: en vez de reducir los poemas a aquello que nos parecería lógico que fueran, hay que tomarlos como son, aunque quede duda sobı $\mathrm{e}$ la autenticidad de los finales y sobre pequeños elementos aislados. $\mathrm{Y}$ hay que intentar comprenderlos a partir de unas normas y leyes de composición que no son, evidentemente, las de una unidad rígida y "lógica». En parte esto se ha hecho ya. Pero la aportación del punto de vista que aquí traemos, más la consideración del modelo homérico, puede

29 P. 111 ss.

30 P. 41 ss.

31 Cf. Aurelio Pérez Jiménez, «Los 'Días' de Hesíodo: estructura formal y análisis del contenido», EMERITA 45, 1977, pp. 105-123. 
ayudarnos a seguir la lucha del poeta para crear a partir de los antiguos géneros otros nuevos con una unidad «sui generis».

\section{LOS GÉNEROS INTEGRADOS EN LOS POEMAS}

Con esto volvemos al principio. Nos hallamos ante dos poemas compuestos, según la opinión más autorizada, en torno al 750 a. C.; bien oralmente, bien dictando el poeta; en todo caso, según el estilo oral tradicional al que también pertenecen los poemas homéricos. Hesíodo conoce a Homero: quizá no nuestro texto, sino otro próximo. Está influido por él en cuanto a temas y estilo, Solmsen y una serie de estudiosos más lo han puesto de relieve claramente. Pero Hesíodo crea géneros literarios nuevos que subsumen otros antiguos, de los que encontramos, a veces, precedentes en el Oriente. Otras veces los precedentes están en Grecia. Y otras, como hemos anticipado, hemos de suponer que en Grecia existieron géneros próximos a los orientales mencionados, sin duda influidos por ellos. Así, pues, antes de hablar de la composición de los poemas hesiódicos, hemos de hacer un análisis de los principales elementos genéricos que contienen.

\section{Los proemios.}

La Ilíada y la Odisea tienen mínimos proemios en los que el poeta pide a la Musa que cante la ira de Aquiles o las peregrinaciones de Odiseo. La voz del poeta es, pues, la voz de la Musa: voz anónima. Pero Hesíodo introduce grandes innovaciones. En primer lugar, sus proemios (dos en Teogonía, uno en Trabajos y Días) son ya poemas líricos de estructura ternaria, en honor de las Musas: se insertan en la tradición de los himnos homéricos y de toda la lírica ${ }^{32}$. De acuerdo con esta tradición, en los versos iniciales de los dos proemios de la Teogonía (1 y 36) Hesíodo anuncia que va a cantar celebrando a las Musas, si bien el estilo épico (conservado en el proemio de Trabajos y Dias) se trasluce todavía en Teogonía $(105,114)$ : el poeta invita a las Musas a cantar. De otra parte, de acuerdo también con la lírica, los dos proemios de Teogonía contienen una referencia al poeta; la directa de $22 \mathrm{ss}$. (el segundo centro del primer proemio) donde se cuenta cómo las Musas otorgaron a Hesíodo el don de la poesía; y la genérica de 94 ss. (tercer centro del segundo

32 Cf. Francisco R. Adrados, Origenes de la Lirica griega, Madrid, Revista de Occidente, 1976 , p. 59 ss., 149 ss. 
proemio). También el proemio de Trabajos y Días contiene una referencia al poeta, al decir éste (10) que va a dar consejos a Perses.

Se trata, pues, de himnos a las Musas en estilo, naturalmente, lírico, aunque mezclen algunos elementos épicos. Pero no son simples himnos como los que se solían ejecutar antes de la epopeya ${ }^{33}$. Evidentemente, la costumbre de cantar un himno a una divinidad antes de la epopeya se ha sintetizado con la técnica de la épica, en la que se invita a la Musa a cantar los sucesos que siguen. $\mathrm{O}$, si se quiere, esta invocación a la Musa sobre el otro modelo, se ha convertido en un himno a la Musa que anticipa el contenido de lo que sigue. Ésta es la gran innovación de Hesíodo, más explícita en Teogonía y en cierto modo resumida en Trabajos y Días.

Puede ser o no cierta la afirmación de Lenz de que el prólogo o proemio de tipo hesiódico que así surge se debe a que el contenido de los poemas era nuevo y debía ser en algún modo anunciado o preparado ${ }^{34}$. En todo caso, al lado de la estructura "abierta" de los poemas homéricos y de la épica en general, y de la estructura ternaria de la lírica, nace una nueva estructura que podríamos llamar binaria; proemio y relato en el caso de Teogonía, proemio y parénesis en el de Trabajos $y$ Días. Estructura binaria porque al menos en el estado en que estos poemas han llegado a nosotros no tienen un epílogo equivalente al proemio inicial.

Hemos presentado en otro lugar nuestros argumentos a favor de que el himno monódico griego adquiere su estructura ternaria, con un contenido mítico central, por influjo oriental ${ }^{35}$. La lírica griega tradicional ha sido fecunda por la oriental: así ha nacido la lírica literaria griega. Pero es un género ya propiamente griego el que Hesíodo toma en préstamo. $\mathrm{Y}$ es innovación suya el convertir un himno de esquema ternario $(a-b-c)$ en proemio o elemento $a$ de un nuevo elemento $b$, del origen que sea. Segunda innovación: el elemento $b$ o centro del proemio anticipa el elemento $b$ o cuerpo del poema. El esquema es como sigue:

\section{Teogonía}

Proemio 1 (Himno a las Musas del Helicón)

$a$ (proemio): voy a celebrar a las Musas del Helicón,

$b$ (centro): que $(\alpha \mathfrak{l})$ danzan en el Helicón y cantan... (anticipo de la Teogonía, cuyos temas se dan en orden inverso), que $(\alpha l)$ iniciaron a Hesíodo, a mí, en la poesía

33 Cf. A. Lenz, Das Proöm des frühen griechischen Epos, Bonn, Habelt, 1980, p. 23

34 Lenz, ob. cit., p. 95.

35 Cf. Orígenes..., cit., p. 190 ss. 
$c$ (epílogo): y me ordenaron celebrarlas siempre al comienzo y al final (cierre del anillo).

Proemio 2 (Himno a las Musas olímpicas)

$a$ (proemio): voy a celebrar a las Musas del Olimpo

$b$ (centro): que ( $\tau \alpha i$ ) celebran a Zeus y cantan temas cosmogónicos y teogónicos (anticipo de la Teogonía),

que ( $\tau \dot{\alpha} \varsigma$ ) nacieron de Zeus y celebran a los dioses (un anticipo más),

que $(\alpha \mathfrak{l})$ marcharon hacia el Olimpo celebrando a Zeus (nuevo anticipo) y honran a los reyes. También a los aedos (apéndice: ह̇k $\gamma \dot{\alpha} \rho . .$.$) .$

c (epílogo): Adiós y celebrad a los inmortales (nuevo anticipo). Contadme todo esto, oh Musas (cierre del anillo) ${ }^{36}$.

\section{Trabajos y Dias}

Proemio único (Himno a las Musas de Pieria)

$a$ (proemio): celebrad a Zeus, vuestro padre,

$b$ (centro): por el cual ( $\measuredangle \vee \tau \varepsilon \delta\llcorner\alpha$ ), según su justicia o injusticia, reciben los hombres premio o castigo (anticipo del tema de la obra),

c (epílogo): escuchadme, sed justos: yo voy a aconsejar a Perses.

Como se ve, los detalles varían: hay un proemio o dos, éstos tienen un centro subdividido a veces, el estilo es puramente lírico o con elementos épicos, varía en el detalle el "sello" personal del poeta. Pero hay algo uniforme: los "centros", introducidos por el relativo, cuentan el mito de las Musas y, en conexión con él, el de Zeus. Parte del mito es el canto de las Musas: y el canto es el anticipo de uno y otro poema.

Dentro del mito de las Musas, efectivamente, se hace alusión a su canto celebrando aquello que luego va a celebrar el poeta, se insiste en que lo canten. Así, los himnos de Hesíodo nos trasladan los himnos de las Musas y éstos anticipan el relato hesiódico que va a seguir ${ }^{37}$. Sus temas esenciales están prefigurados; y el papel central de Zeus en ambos poemas, también.

Esta es la gran innovación de Hesíodo para presentar ese combinado de géneros diversos que unifica en cierto modo en sus poemas. En buena medida, con ayuda de los proemios en cuestión: lírica griega adaptada a una nueva circunstancia. Ya anticipan la épica cosmogónica y divina, ya la parénesis ${ }^{38}$.

36 No puede calificarse de "proemio interior", como propone Lenz, ob. cit., p. 130.

37 Cf. Origenes..., lug. cit.

38 El paralelismo del proemio de Trabajos y Dias y los de Teogonía excluye la 
Por si hacía falta alguna prueba de la originalidad de Hesíodo, baste considerar los comienzos de los poemas orientales a que hemos hecho referencia. El Enuma Elish comienza directamente: "Cuando en lo alto el cielo aún no había sido nombrado...»; e igual el Génesis: «En el principio creó Dios los Cielos y la Tierra...». El reinado de los Cielos tiene ciertamente un proemio, pero es muy diferente: "Que me oigan (...) y (...), que son los dioses primigenios, que me oigan...». De un modo semejante, en El Canto de Ullikummi el poeta anuncia su canto: "Al dios... a Kumarbi... voy a cantar». Las colecciones de proverbios sin destinatario concreto comienzan directamente, sin proemio. Aquellas otras en que un padre se dirige a su hijo o hay un esquema semejante, el comienzo es simplemente la presentación de la situación en que se comienza a impartir los consejos: así continuó siendo en derivados como el Ahikar o las colecciones indias de fábulas, el esquema llegó a nuestras colecciones medievales como la de Pedro Alfonso y El Conde Lucanor. Igual es el caso del almanaque o calendario agrícola sumerio: "En los tiempos antiguos un labrador instruyó a su hijo...».

\section{Cosmogonias, Mito de la Sucesión, Epica divina, Genealogias.}

Hemos visto que en los poemas orientales a que hemos hecho referencia la parte cosmogónica está estrechamente unida al Mito de la Sucesión: así en Hesíodo también. Participa, pues, nuestro poeta de la tradición poética iniciada en el Oriente. Ello se confirma porque los pasajes cosmogónicos de Ilíada (14.200 ss., 274, 278 s., 15.185 ss.) presentan una vez más la mezcla de unos y otros elementos. Aquí tenemos a Océano y Tetis como padres de todo; en ellos se refugió Hera cuando la batalla de Zeus contra Crono y los Titanes, arrojados todos ellos al Tártaro; y se siguió el reparto del mundo entre los tres dioses hermanos Zeus, Posidón y Hades, quedando indivisos el Cielo y la Tierra. Son alusiones a un conjunto único, en parte coincidente con la Teogonía, en parte no: en ésta Océano y Tetis no están en el origen, sino que son hijos de Urano y Gea.

Así, lo mismo si Hesíodo conoció los pasajes homéricos referidos, como considera probable Solmsen ${ }^{39}$, que si las coincidencias se explican porque los mitos se habían difundido ya en Grecia (recuérdese el culto de Crono en diversos lugares y el de Rea en Creta), es claro que ambos poetas están en la línea de sus predecesores asiáticos. Nótese que no

idea de su carácter interpolado, pese a la noticia de Pausanias IX 31 de que faltaba en un texto visto por él en Beocia ( $\mathrm{y}$ a la opinión de algunos modernos).

39 Ob. cit., p. 10 ss. 
hay una línea mítica única que llegue a Grecia: el comenzar por el Cielo y la Tierra tiene equivalentes fuera de Grecia, el comenzar por las aguas también. Pero en ambos casos, insisto, existe el rasgo común de unir Cosmogonía y Mito de la Sucesión.

La primacía de las aguas es clara en el Enuma Elish, donde aparecen Apsû y Tiamat, las aguas masculinas y femeninas, como Océano y Tetis; Anšar y Kišar, el horizonte celeste y el terrestre, vienen después; y luego Anu (el Cielo) y su descendiente Ea, semejante a Crono (pero a quien mata es a Apsû, no a Anu el equivalente de Urano). Esta misma primacía de las aguas (y de la oscuridad) se da en el Génesis, donde sólo en un segundo momento crea Dios el Cielo y deja despejada la Tierra. En cambio, las aguas no parecen jugar un papel importante ni en el mito fenicio ni en El reinado de los Cielos: en éste, tras el borroso Alalu inicial, aparece Anu (el Cielo) y más tarde la pareja formada por el Carro y Tierra, que procrea hijos. El tema de la separación del Cielo y la Tierra aparece en El canto de Ullikummi.

Es sabido que ni las cosmogonías ni el Mito de la Sucesión presentan un aspecto uniforme: véase en Walcot ${ }^{40}$ una relación de diferencias, pueden añadirse muchas más. En Grecia quedaron insertos en dicho mito, sin duda sobre precedentes indígenas, dioses como Crono, Rea y Zeus: el último un dios indoeuropeo, los primeros seguramente del sustrato indígena, común con Asia Menor. Pero se vacila sobre los detalles, por ejemplo, la posición de Urano-Gea y de Océano-Tetis. Y existían otras cosmogonías que también se reencuentran en forma más o menos próxima fuera de Grecia: así la de Museo, que comenzaba por el Tártaro y la Noche, la de Epiménides, por el Aire y la Noche (de donde nació el Tártaro), la de los órficos, por la Noche y el huevo cósmico, dentro del cual está Fanes o el Amor, tema que influyó en Hesíodo ${ }^{41}$. En Alcmán 5 PMG hallamos todavía restos de otra cosmogonía en que Gea era reciente, posterior a Poros (Comienzo), Tecmor (Fin) y Oscuridad, a su vez posteriores a un primer momento equivalente al Caos de Hesíodo. Nótese la importancia del papel de la Oscuridad y la Noche, presente también en el Génesis y en el mito fenicio; del Amor, al que no es ajeno el Pothos «Deseo» del mismo mito fenicio; y del huevo cósmico, que reencontramos en pueblos numerosos y llega al Kalevala finlandés.

En resumen: proponemos una penetración en Grecia de diversos mitos cosmogónicos y diversas versiones del Mito de la Sucesión. En Grecia se reelaboraron de diversas maneras, asociándose a mitos y dio-

40 Ob. cit., p. 6 ss.

41 Cf. el artículo de Schwabl, «Weltschöpfung», en $R E$.

LIV, $1.0^{\circ}-2$ 
ses griegos. Pero insistimos en un punto: en la asociación de los dos temas en Homero y Hesíodo, lo que no puede ser independiente de los poemas orientales.

Ahora bien, una vez hecha la adecuada referencia a las coincidencias, hay que insistir en las diferencias. No solamente en los detalles diferenciales de Crono y Ea (que mata a Apsû) y Kumarbi (que castra a Anu y queda preñado de él), por ejemplo, sino en rasgos más esenciales. En los poemas orientales el elemento genealógico es mínimo: se limita a pasajes como Enuma Elish 10 ss.: «Lajmu y Lajanu fueron creados... Anšar y Kišar fueron creados... Anu fue su hijo... Anu engendó á su imagen a Nudimmud...». En Hesíodo es máximo. De un lado, Hesíodo simplifica los esquemas, todo se centra en la línea Urano/Gea-Krono/ Rea-Zeus; de otro, trata de seguir, aunque sea a costa de abandonar momentáneamente esa línea central, la descendencia de todas las parejas, tejiendo una red genealógica que abarca el mundo entero. Para ello, sin dejar de conservar restos de los procesos partenogenéticos que son esenciales en El reinado de los Cielos, por ej., todo se centra en la unión sexual y, muy especialmente, en la de Gea/Urano, Crono/Rea y Zeus/sus diversas esposas. Hay luego las ramas colaterales, los sucesivos incestos, llevando todo ello a un complejo mundo natural, divino y heroico. Aunque falte propiamente la creación del hombre, presente en el Enuma Elish y apenas si aludida en Teogonia en el episodio de Prometeo.

De otra parte, en los poemas orientales hallamos episodios épicos ligados al mito de sucesión: episodio Anu/Kumarbi en $E l$ reinado de los Cielos, triunfo final de Marduk en el Enuma Elish, prácticamente todo en Hedammu y El Canto de Ullikummi (estos monstruos son vencidos por Kumarbi y Tešub, respectivamente). Esta "épica divina” aparece otras veces fuera de este contexto, así, en Sumer, en el Gilgamés, y en Grecia en la Teomaquia de la Ilíada y en diversos lugares más. Lo característico de Hesíodo es que esa épica divina cobra un papel muy importante. A veces pisa seguramente sobre la oriental, así en la "aristea" de Zeus, comparada con el triunfo de Marduk, siendo a su vez su rival Tifeo comparado con Hedammu y Ullikummi. Pero adquiere más detalle, más relieve. Insistiremos en esto.

Nuestra tesis es, pues, simple. Hesíodo escribe, en su Teogonía, un poema que, sobre la tradición oriental, pero con diferencias importantes en el detalle, une una Cosmogonía con el Mito de Sucesión. Ahora bien, su modelo o modelos contenían ciertos elementos genealógicos y de "épica divina" que le dieron pie para ampliar estos aspectos en su poema. 
Pues bien, pensamos que el acceso de Hesíodo a sus fuentes no es directo. Que, de una parte, el complejo Cosmogonía-Mito de la Sucesión era ya un género literario griego, con ejemplares múltiples. Que, de otra, existían en Grecia poemas genealógicos que sirvieron de modelo a su ampliación. Y que lo mismo puede postularse en cuanto a su otra ampliación, la "épica divina». Hesíodo no pudo inventar todo esto y hay datos tanto de contenido como formales de que bebió de una rica tra. dición, sin duda de poesía oral, que coexistía con la tradición de la épica homérica, que también conoció. Ambas tradiciones, por lo demás, se interpenetraban a veces: lo hemos visto para el conjunto CosmogoníaMito de Sucesión, puede demostrarse también para los otros elementos.

El hecho es que en Grecia encontramos indicios de la existencia de una poesía de los diversos tipos mencionados en fecha anterior a Hesíodo. Por lo que respecta al conjunto de la Cosmogonía y el Mito de Sucesión, ya hemos dicho que la versión hesiódica contiene elementos que ya conocía Homero, algunos íntimamente unidos con mitos muy difundidos. Hemos insistido, de otra parte, en que la versión hesiódica no reproduce con exactitud ninguna de fuera de Grecia y contiene rasgos propiamente griegos. No es de creer que se deba al solo Hesíodo, en efecto, el relieve dado a la descendencia de Tierra (en sus dos versiones de Gea y Rea), ni el paso de una sección centrada en Gea a otra centrada en Urano: de un universo matriarcal a uno patriarcal, véase más abajo. Por otra parte, al aparecer en Grecia tantas cosmogonías diferentes, emparentadas con las orientales, es claro que hubo una difusión amplia de estos temas en Grecia. Es un estadio intermedio que no podemos negar. Todo esto confirma que los influjos orientales en Grecia que ahora nos interesan deben remontar a época micénica, como propuso West ${ }^{42}$. Hubo en Grecia, sin duda, una asimilación de los temas orientales a la propia mitología, a las propias tradiciones en torno a una diosa madre. $\mathrm{Y}$, a partir de aquí, poesía oral y tradicional, que está en la base de Hesíodo.

Igual hay que decir de las Genealogías, pero con un matiz diferencial. este tipo de poesía no sabemos que floreciera en el Oriente. Fue una originalidad de Hesíodo, creemos, unirlo al esquema de origen oriental de que venimos hablando: ofrecía asideros, ciertamente. La poesía genealógica y los catálogos se han atribuido tradicionalmente a Beocia y Lócride, es decir, a territorios que son el uno la patria de Hesíodo mientras que el otro está relacionado con su leyenda. Se ha notado que los catálogos homéricos del canto II de la Ilíada y del XI de la Odisea con-

42 Hesiod, Theogony, cit., p. 28 ss. 
tienen numerosos elementos beocios. Sobre este tema puede consultarse con provecho a Kirk ${ }^{43}$. Hay que insistir en que este tipo de poesía halla eco no sólo en Teogonia, también en Trabajos y Dias y en una obra dedicada a ella especialmente, el Catálogo de las Mujeres o Eeas (y Las grandes Eeas, si se trata de una obra independiente). Paralelamente, no hay duda de que la "épica divina» existía en Grecia y ha dejado huella tanto en Homero como en Hesíodo y en la épica y lírica en general.

El estudio de la lengua y las fórmulas de Hesíodo confirma la existencia en él de elementos no homéricos, que hemos de atribuir a los tipos de poesía a que venimos refiriéndonos. El libro de Edwards arriba aludido habla de los elementos lingüísticos occidentales, unidos a otros jonios de tipo reciente ${ }^{44}$. Son comunes a veces a Teogonía y Trabajos $y$ Dias. Que la diferencia lingüística respecto a Homero sea solamente el resultado de una evolución secundaria, como propone R. Janko ${ }^{45}$, no parece creíble. Este autor intenta interpretar como secundarias todas las diferencias respecto a Homero. $\mathrm{Y}$ es cierto que hay renovación de antiguas fórmulas, pero también elementos independientes de él.

En el dominio en que esto se echa de ver mejor es en el de las fórmulas. Ya C. O. Pavese ${ }^{46}$ adelantó algunas conclusiones, un tanto exageradas por lo demás, sobre la lengua épica continental. Ultimamente ha vuelto a resumir sus conclusiones ${ }^{47}$ y cito más concretamente un artículo anterior de J. de Hoz, publicado en esta misma revista ${ }^{48}$, en el que se desarrollaban algunas cosas apuntadas por J. A. Notopoulos ${ }^{` 9}$ y A. Hoekstra ${ }^{50}$ : en él se ponía de relieve la existencia de una serie de fórmulas ya genealógicas, ya cosmogónicas, ya participando de ambas características que son independientes de las de Homero. No es que no haya coincidencias a veces: la épica griega como la oriental, contiene ya elementos genealógicos. Es que en Hesíodo aparecen nuevas series de fórmulas. Pero más decisivo aún es, me parece, el material formulario acumulado y clasificado en el libro de Franz Krafft ${ }^{51}$. Aquí, en un

43 Art. cit., p. 68 ss.

44 Ob. cit., p. 1.

45 Ob. cit., p. 70 ss.

46 Tradizioni e Generi Poetici della Grecia Arcaica, Roma, Edizioni dell'Ateneo. 1972.

47 «Poesia ellenica e cultura orale», en 1 poemi epici..., cit., pp. 231-259.

48 "Poesía oral independiente de Homero en Hesíodo y los himnos homéricos», EMERITA 32, 1964, pp. 283-298.

49 "Homer, Hesiod and the Achaean heritage of oral poetry", Hesperia 29, 1960, pp. 177-179.

so "Hesiode et la tradition orale", Mnemosyne 16, 1957, pp. 193-225.

51 Vergleichende Untersuchungen $z u$ Homer und Hesiod, Gotinga, Vandenhoek und Rupprecht, 1963. 
apéndice a partir de p. 193, figuran fórmulas solamente hesiódicas (en inicio, centro o fin de verso, versos completos también). Podrían aumentarse fácilmente, pues se refieren sólo a Teogonía y Trabajos y Días, no a los Catálogos.

Ciertamente, Hesíodo puede imitarse a sí mismo (Trabajos y Dias, sobre todo, reelabora partes de Teogonia) y no hay que olvidar que nuestro conocimiento de la épica griega es fragmentario. Aun así, resulta una conclusión notable que la gran mayoría de estas fórmulas se refieren a temas cosmogónicos, genealógicos y, también, a poesía gnómica. Ahora bien. Una fórmula es el resultado de una larga tradición: Hesíodo tenía precedentes en Grecia en los campos mencionados. Precedentes que se colocan entre él y sus remotas fuentes orientales.

Naturalmente, no vamos a hacer aquí un estudio completo, que podría realizarse con los materiales que aparecen en las obras mencionadas. Estos materiales se refieren en parte a temas cosmogónicos y del Mito de Sucesión; en parte al mito divino en general; en parte a fórmulas genealógicas. Naturalmente, hay transiciones, puesto que el mito divino en general y las genealogías aparecen íntimamente unidos con el núcleo de la Cosmogonía y el Mito de Sucesión. En cierta medida, se trata de elementos que pueden combinarse con la épica en general, a veces están próximos a otros homéricos. Pero en buena parte, como decimos, son nuevos.

Comenzamos por ese núcleo, procediendo resumidamente y sin dar las referencias, que pueden hallarse en las obras mencionadas. Tenemos fórmulas, entre otras:

En primer lugar, de los principios más antiguos. Hay fórmulas de

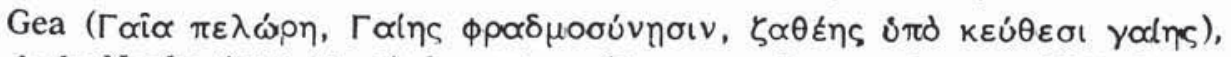

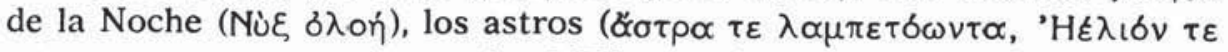

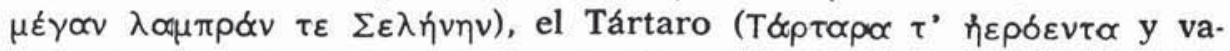
riante). No hay repetición de un evidentemente formulario Oủpœvòv

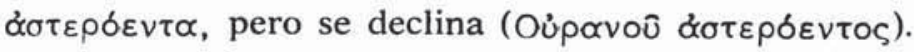

Hay también fórmulas para la descendencia de Gea y Urano ( $\Gamma \propto\lceil\eta \eta$

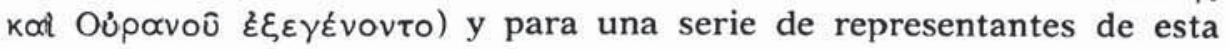

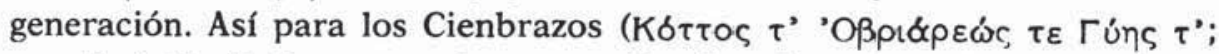

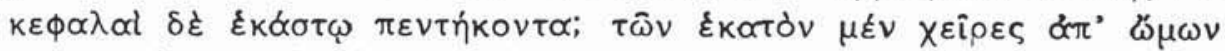

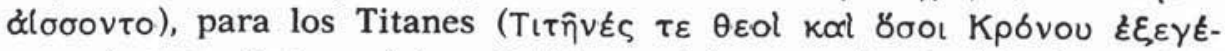

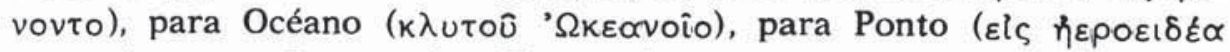

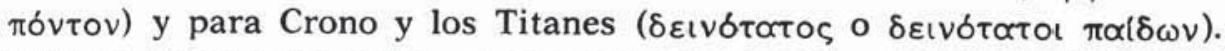
Pero es sobre todo Crono el mejor representado en el lenguaje formu-

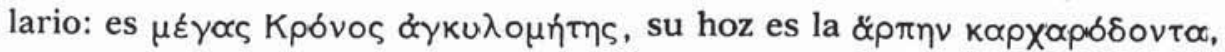

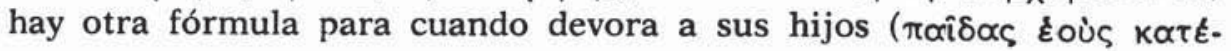




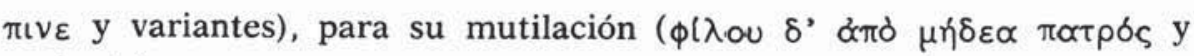
variante).

En la siguiente generación hay fórmulas diversas: para Styx ( $\Sigma \tau \dot{\imath} \xi$

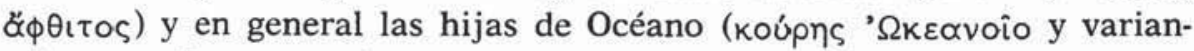

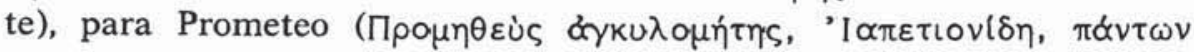
$\pi \varepsilon \rho \uparrow \mu \dot{\delta} \delta \varepsilon \alpha \varepsilon l \delta \omega \varsigma$ ). Pero sobre todo para Zeus y el Olimpo (fórmulas a

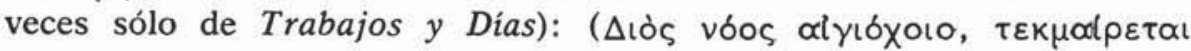

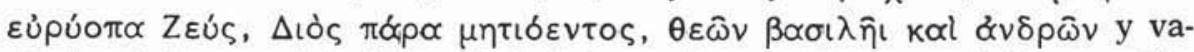

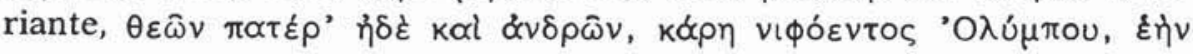

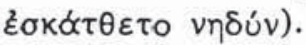

También hay fórmulas no homéricas sobre los dioses en general.

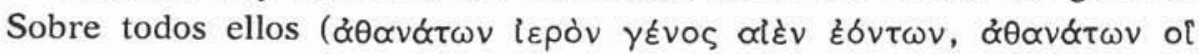

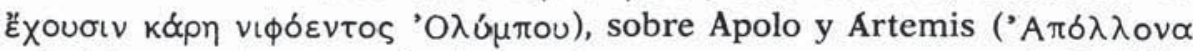
$\kappa \propto \chi$ "A

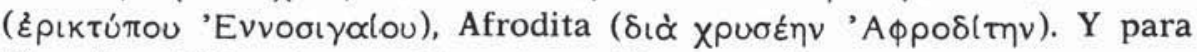

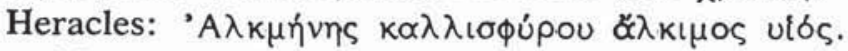

No parece dudoso, después de lo dicho, que Hesíodo trabajaba no directamente sobre modelos orientales, sino sobre modelos griegos de poesía oral cosmogónico-teogónica derivados de aquéllos, pero con notable originalidad en la adaptación de los mitos y en la forma. Es esta originalidad la que demuestra su existencia: evidentemente, estos poemas estaban próximos a la épica griega en general, que conoce algunos de sus motivos y comparte en grandísima medida su lengua y sistema formulario. Pero hay una diferencia clara de contenido y, aunque menor, una diferencia de lengua y de sistema formulario. De otra parte, existían también sistemas formularios relativos a diversos dioses, aquí mencionados: habría que añadir lo expuesto por de Hoz sobre el sistema de Deméter. Hesíodo sacó partido, también, de este tipo de poesía al ampliar el esquema central de su obra teogónica con referencias a dioses como Afrodita, Atenea, etc.

También lo amplió, como hemos dicho, con elementos genealógicos que van mucho más allá de los de sus fuentes orientales y de los de Homero (aunque en parte sean comunes con él). De una poesía genealógica griega independiente, ya hemos hablado: hay no sólo testimonios sino poemas conservados más o menos íntegramente. Añadamos ahora las huellas de estos sistemas formularios genealógicos en Teogonía. En ellos predomina un planteamiento femenino o matriarcal, si se quiere: la diosa o la mujer está casi siempre en el centro, a partir de ella se establecen las relaciones de descendencia. Esto coincide tanto con el papel central de Gea en la primera parte de la Teogonía como con la existencia de poemas genealógicos «femeninos» del tipo de las Eeas 
(cf. también el catálogo de las heroínas en el canto XI de la Odisea, ya citado). Todo esto es muy diferente de lo que hallamos en las Cosmogonías orientales: Hesíodo se basa en una tradición indígena con que amplía su obra. Claro que a partir de un momento domina otro principio, el patrilineal a partir de Urano.

Volvamos a las fórmulas genealógicas, que atestiguan una tradición de poesía genealógica parcialmente independiente. Parcialmente: en Hesíodo hallamos fórmulas homéricas, las de tipo hesiódico que hemos de ver se encuentran, alguna vez, en Homero. De otra parte, el sistema ha penetrado en el mito cosmogónico, hemos presentado antes la fórmu-

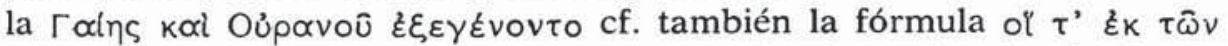

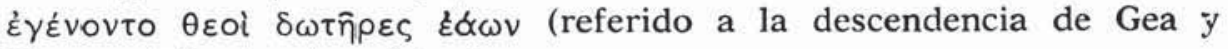
Urano; el final es homérico).

Como hemos dicho, estos sistemas formularios son predominantemente femeninos. Añadamos que frente al tipo homérico $(\varepsilon) \mu l \gamma n$ $\phi i \lambda o ́-$

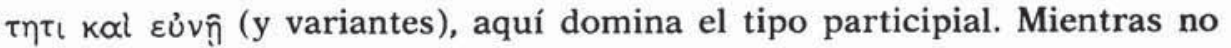
se diga otra cosa, las fórmulas a que nos referimos están documentadas en Teogonía y, eventualmente, en las Eeas y los himnos homéricos: no en Il. ni Od.

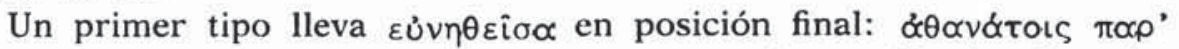

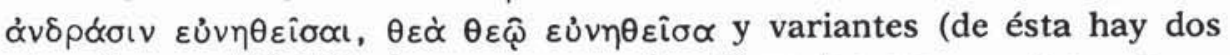

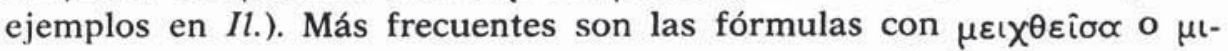

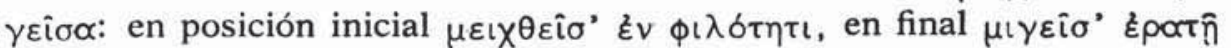

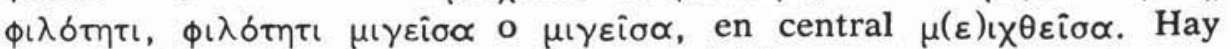
también fórmulas con $\delta \pi \circ \delta \mu \eta \theta \varepsilon i ̂ \sigma \alpha$ : inicial $\gamma \varepsilon i v \propto \theta^{\circ} \dot{\delta} \pi \circ \delta \mu \eta \theta \varepsilon i \hat{i} \sigma \alpha, \mathrm{y}$ variantes, hay también un uso central (_- ] jं

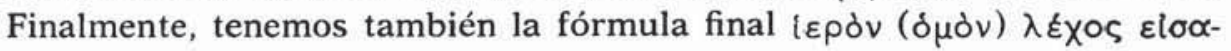

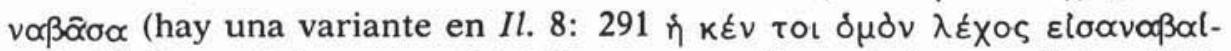
vol). Y, fuera del uso participial, un verso formulario completo: $\alpha \theta \dot{\alpha}$ -

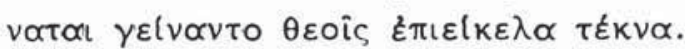

El tipo masculino es minoritario y creo que secundario. Su fórmula

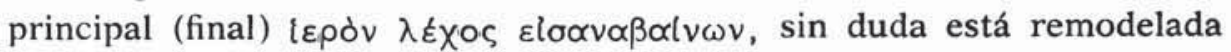
sobre la fórmula anterior. Aparte de esto tenemos solamente $\theta \propto \lambda \varepsilon p \eta \nu$

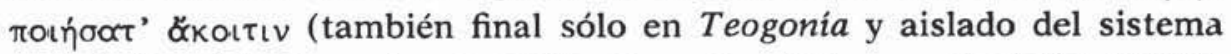

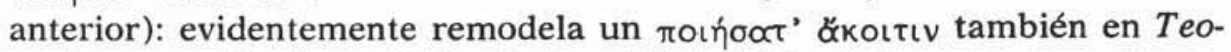
gonia pero, además, en $O d$. e incluso $I l$. Inútil insistir en el gran número de elementos formularios comunes con Homero.

Todo esto parece demostrar que el modelo de las ampliaciones hesiódicas del complejo de tradición oriental Cosmogonía + Mito de Sucesión, está en poesía genealógica "femenina» que tenía existencia independiente en Grecia, pero que estaba emparentada con elementos genealógicos de 
la épica. Esta influyó también a través de mitos divinos y, veremos, de Homero. Hesíodo logró así completar su poema para, sin abdicar de sus modelos remotos, ofrecer en él una descripción completa del mundo divino y natural.

3. Poesía parenética. Otros modelos cosmogónicos.

Damos el nombre global de poesía parenética a una serie de géneros de tradición oriental a los cuales ya nos hemos referido. Se trata, de un lado, de la parénesis que llamaríamos personal (consejos a un hijo, a un rey) y de otro de la general (preceptos dirigidos al lector). Vimos que calendarios agrícolas y hemerologios son subespecies del mismo género: consejos en relación con las labores del campo y con la conducta a seguir en los diferentes días del mes. Pueden tener un enfoque personal o general.

Casos especiales son el apartado hesiódico sobre los trabajos de la navegación, sin precedentes orientales que sepamos y pura derivación del calendario agrícola, y la sección de mitos y fábulas. El carácter parenético de esta sección no puede ponerse en duda; pero sobre su origen y su papel en Trabajos y Dias hemos de decir algunas cosas.

Trabajos y dias es, según generalmente se reconoce, una obra posterior a Teogonía. A veces rectifica o profundiza los temas de esta obra, así en los pasajes sobre las dos Erides y sobre Prometeo. Sucede que en Teogonia, al contrario que en poemas orientales como el Enuma Elish, el tema de la creación del hombre sólo oblicuamente es abordado, a través del tema de Prometeo, que es una contrafigura del dios $\mathrm{Ea}^{52}$. Hay, ciertamente, alusiones a su condición a propósito de las menciones de Eros, de ciertos hijos de la Noche, del mismo nuevo orden establecido por Zeus. Evidentemente, Hesíodo decidió crear una nueva obra, de tema humano: Trabajos y Días. Una vez más, el origen del hombre es solamente aludido, pero el poeta se centra en el tema de Zeus, defensor de la justicia, y en la conducta que el hombre debe seguir para recibir el favor del dios y no el castigo.

Como pendant a Teogonía, el poeta antepone un proemio lírico a un género de origen oriental: en este caso, el o los géneros parenéticos. El proemio resume los dos de Teogonía. Y los adapta: su centro se refiere a Zeus como dios de la Justicia, anticipa así el tema del poema. Pero hay que advertir que en los modelos orientales y en lo que sabemos

52 Cf. mi trabajo «Ibico 61 y el influjo del Gilgamés en Grecia», en prensa en Aula Orientalis, Barcelona. 
de la poesía parenética en Grecia, el enfoque es puramente práctico, hay que proceder de tal o cual manera para no crearse problemas: no aparece el dios que premia o castiga. Hesíodo ha debido adaptar esos esquemas a su propia religión de Zeus, a lo que, en realidad, ya se anticipa en Teogonía y aquí está más desarrollado.

Pero volvamos a los géneros parenéticos de Trabajos y Dias. En términos generales bien puede decirse que se trata de una parénesis dirigida a Perses: series de consejos con un ${ }^{\top} \Omega$ $\Pi \varepsilon$ pon en cabeza o en lugares arbitrarios, series yuxtapuestas mediante una composición laxa en la que son los ecos verbales los que habitualmente hacen pasar de unos temas a otros o volver a los primeros, según se ha estudiado varias veces. Es en la primera sección 11-289, tras el proemio, donde esto se ve más claramente. Pero no es esto todo.

Tenemos, también, una parénesis dirigida a los reyes: $248{ }^{\top} \Omega$ Bơ $\lambda \bar{\varepsilon} \varepsilon \varsigma$ y lo que sigue. Hay, luego, series, del tipo de la "parénesis general" de que hablábamos. En términos literales esto es exacto de la serie de máximas 695-764, mientras que la serie anterior, la que sigue a los mitos y fábula iniciales y se extiende de 293 a 383, sólo en un momento (299 $\varepsilon \rho \gamma \alpha \zeta \varepsilon v, \Pi \varepsilon \rho \rho \eta)$ presenta una exhortación dirigida directamente a Perses. Claro que, si se quiere, se pueden considerar como cabeza de la serie los versos 286-292 en que Hesíodo anuncia que va a contar algo

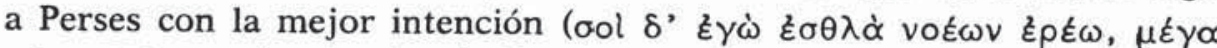

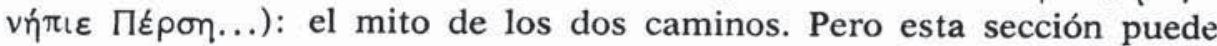
considerarse también como un nuevo mito, en la serie de los anteriores. Por otra parte, el calendario (383-617) sólo presenta dos menciones, y

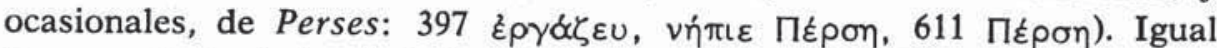
hay que decir de los trabajos de la navegación (616-662), que comienzan con un "tu" ambiguo $(\varepsilon l \delta \varepsilon \sigma \varepsilon)$ y citan a Perses dos veces $(633,641)$, en el pasaje inicial biográfico. Perses no figura en absoluto en "Los días", 765-828.

Da la impresión de que Hesíodo ha combinado varios tipos de parénesis, que sólo ocasionalmente se acuerda de unificar con el nombre de Perses. Conforme avanza el poema, más se olvida de él. Y lo mismo del segundo principio de unificación, el centrado en torno al tema de Zeus y su justicia. Es omnipresente en los mitos y fábulas iniciales, tras el proemio (11-284), lo mismo en el centro de los relatos que, sobre todo, en los elementos $c$ o epílogos. Luego, en la primera serie de máximas Zeus aparece dos veces $(333,379)$ en su función de premiar al hombre justo que trabaja. A partir de aquí las menciones de Zeus (465, $488,565,638,668,724)$ son no sólo raras, sino, sobre todo, puramente ocasionales. 
La unificación que Hesíodo ha introducido en torno al tema de Zeus justiciero y de los consejos a Perses y a los reyes se diluye conforme avanza el poema. De la parénesis personal se pasa insensiblemente a la genérica de varios tipos. Domina cada vez más la posición puramente práctica, no religiosa.

El esfuerzo realizado por Hesíodo para poner de relieve esta última, en relación con el tema de la justicia de Zeus, se ha traducido formalmente en destacar algunos de los complejos parenéticos con "oh Perses" o "oh reyes" poniéndolos en cabeza de los epílogos de mitos y fábulas. Esto es importante y merece un comentario.

Las colecciones orientales de proverbios contienen, junto a máximas o proverbios propiamente dichos, símiles y fábulas animales. Y ello lo mismo las personales que las generales. He remitido ya a mi tratamiento del tema en mi Historia de la fábula... I, donde se da la bibliografía pertinente. Como digo allí, las colecciones en cuestión contienen precep. tos, máximas, simples apotegmas, adagios, paradojas, chanzas, reproches, cumplidos, deseos, símiles, cuentos y, desde luego, fábulas. La semejanza del contenido con Trabajos y Días es puesta de relieve por Walcot ${ }^{53}$. No falta, incluso, la mención de Enlil, semejante a la de Zeus, "es ley de Enlil para los hombres que el hijo siga los consejos de su padre» (de la colección sumeria El padre y su hijo desobediente, en West ${ }^{54}$ ).

Pero la fábula del halcón y el ruiseñor en Trabajos y Dias, primera fábula griega, es narrada en 302 ss. en una forma muy original: tras contársenos que el halcón contesta al ruiseñor suplicante que lo devorará, o soltará, según desee, pues es más fuerte, siguen series parenéticas dirigidas a Perses (213 ss.), los reyes (248 ss.), Perses otra vez (274 ss.), que extraen la consecuencia explícita: hay que seguir la justicia de Zeus, porque éste estableció una ley para las bestias, devorarse unas a otras, y otra para los hombres, seguir la justicia. La fábula y su contexto parenético han quedado en una nueva relación: ahora se trata de una fábula-ejemplo, como será luego habitual a partir de Arquíloco,

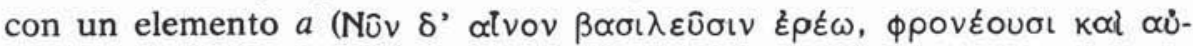
toîs), uno $b$ (el relato de la fábula) y un epílogo $c$ fragmentado como vemos en tres partes, la tercera de las cuales acaba de explicar la moraleja de la fábula y concluye con la afirmación general de que Zeus da riqueza al que conoce la justicia, daña a la descendencia del injusto y favorece a la del justo. Sigue la nueva exhortación a Perses sobre el tema de los dos caminos y toda la primera serie de máximas y preceptos.

53 Ob. cit., pp. 87, 92 s.

54 Hesiod, Works and Days, cit., p. 5. 
Hesíodo ha aislado una fábula y la ha convertido en fábula-ejemplo de estructura ternaria, dando así el modelo para todo un género. El epílogo se amplía desmesuradamente para convertirse en una verdader a colección de máximas o proverbios destinada a Perses. De esta manera, la colección no sigue directamente al proemio, sino a través de este intermedio, que permite insistir más directamente en el tema de la justicia de Zeus.

No se puede decir que Hesíodo usara la fábula como ejemplo por primera vez: las colecciones de preverbios "personales" la usan ya así, explícita e implícitamente. Cuando, por ejemplo, Ahikar dice una y otra vez (en Ahikar 8) "hijo mío, has sido como tal o cual animal que...» (un animal que realiza una mala acción, a veces para recibir castigo), no actúa en forma diferente que Hesíodo narrando a Perses la fábula del halcón y el ruiseñor. Cierto que el Ahikar es más reciente que Hesíodo, pero pienso que continúa modelos previos. Lo que es nuevo es el singularizar la fábula, darle una estructura ternaria y colocar dentro de ésta como elemento $c$ largas series parenéticas. Sin duda, el modelo está en el mito-ejemplo, tal, por ejemplo, la historia de Meleagro en el canto IX de la Ilíada. En Arquíloco, fábulas, mitos y anécdotas desempeñan el mismo papel de ejemplos ${ }^{55}$.

Todo esto nos lleva a otro punto: la fábula del halcón y el ruiseñor cierra la parte introductoria de Trabajos y Días (antes del tema de los dos caminos y de la primera serie parenética), pero antes de ella, tras el proemio 1-10, hay una serie de mitos que desempeñan ya prácticamente igual función y tienen la misma estructura. Son mitos-ejemplo de estructura ternaria $a-b-c$ y se caracterizan por referirse a temas de los orígenes del mundo, en realidad cosmogónicos: las dos Erides, Prometeo y Pandora, las edades del mundo. Son mitos etiológicos: explican el porqué de las desgracias de los hombres actuales y ejemplifican el poder de Zeus y su dedicación a la justicia. En los tres el elemento $c$ o epílogo es parenético: es el mismo procedimiento para ligar el elemento parenético y el tema de Zeus justiciero que ya conocemos.

Concretamente, el mito de las Erides (pura creación de Hesíodo, que corrige lo dicho por él mismo en Teogonía $225 \mathrm{~s}$.) comienza en 11 con un relato (elemento $b$, el proemio de la obra suple la falta de $a$ ) y concluye con el elemento $c$ en 27 ss.: es una serie parenética que empieza con "Oh Perses" e incluye el consejo de seguir las leyes de Zeus y no la Eris mala.

55 Para todo esto, remitimos a nuestra Historia... I, pp. 43 ss., 383 ss. 
El segundo mito es el de Prometeo y Pandora, reelaboración como dijimos del paralelo en Teogonía. Comienza con un relato $(b)$ ligado a lo anterior con үóp "pues». Explica las desgracias de los hombres actuales por causa de los males que se escaparon de la tinaja de Pandora y concluye con un breve elemento $c$ : no es posible evitar la voluntad de Zeus, es decir, el fracaso final de Prometeo era previsible y tiene por consecuencia las desgracias de la humanidad.

El tercer mito, en cambio, anticipa la estructura de la fábula con sus elementos $a-b-c$. Comienza en 106 ss. con $a$ ( $(\mathrm{Si}$ quieres, voy a contarte otro mito...») y continúa con $b$, el relato de las edades sucesivas de oro, plata, de bronce, de los héroes que van degradándose y vienen siempre por voluntad de Zeus. El elemento $c$ se introduce en forma anómala, "ojalá no hubiera yo nacido entre los quintos hombres..." (174 ss.) y contiene la descripción de las desgracias de esta edad de hierro en que no se respeta la justicia y que Zeus destruirá.

Todo esto queda bastante alejado, como ya lo estaba la fábula del halcón y el ruiseñor, de las antiguas colecciones parenéticas, aunque secundariamente hayan sido introducidas como elemento $c$ en algunos momentos. En realidad, enlaza con los mitos cosmogónicos de Teogonia, aunque aplicándoles a la interpretación del destino humano en relación con los temas de Zeus y la justicia. Hay que decir que Hesíodo ha dado al tema de Prometeo-Pandora una organización nueva y original ${ }^{56}$. Pero que también aquí sigue modelos orientales. Remito a mi artículo ya citado, a Walcot ${ }^{57}$ y a un libro de Mme. Duchemin ${ }^{58}$. El mito de las edades, para el cual remito a West ${ }^{59}$, también tiene modelos orientales.

Parece, pues, que en Trabajos y Días Hesíodo ha utilizado no sólo colecciones de proverbios que ha yuxtapuesto o fundido, según los casos, y de las que ha extraído una fábula para ponerla en cabeza en condiciones especiales, sino también literatura cosmogónica de tradición oriental, igual que en Teogonía. Pues por más que los orígenes de la fábula sean comunes con los del mito y que temas como el de Prometeo hayan sido tratados luego en Grecia en contexto fabulístico, no imaginamos la existencia de estos temas en colecciones de proverbios. Si buscamos paralelos orientales hemos de acudir a la sección final del Gilgamés, en que la posición del héroe que busca la inmortalidad, así como el tema de Utnapistim o Atrahasis y Ea que le salvan del Diluvio, están emparentados, como he hecho ver en un lugar ya citado, con el

56 Cf. Otto Lendle, Die Pandorasage bei Hesiod, Würzburg, Konradtriltach, 1957.

57 Ob. cit., p. 55 ss.

58 Prométhée, Paris Les Bclles Lettres, 1974.

59 Ob. cit., p. 172 ss. 
tema de Prometeo (que se enfrenta a Zeus como Ea a Enlil en beneficio de los hombres, que en ciertos mitos trae a los hombres la ambrosía y es su creador y que es padre de Deucalión, el Noé griego). O hemos, también, de acudir a diversos relatos cosmogónicos sumerios en que se incluyen mitos etiológicos comparables a los aquí reseñados: los de Enki y el orden del mundo, Enki y Ninhursaq y Enlil y Ninlil ${ }^{67}$.

Así, pues, en Trabajos y Días Hesíodo ha introducido, tras el proemio lírico que hace de prólogo, diversos temas míticos de tipo cosmogónico, pero enlazándolos ya con series de preceptos "personales»: igual hace con una fábula, extraída de las colecciones de proverbios de que hablamos y convertida en fábula-ejemplo sobre el modelo del mito-ejemplo; a partir de aquí, añade una serie de colecciones de proverbios en la forma que hemos indicado.

Ahora bien, igual que en el caso de la Teogonía, también aquí hay que suponer que los modelos orientales a que hemos hecho referencia no han influido en Hesíodo directamente, sino a través de una literatura griega tradicional que los había absorbido bien que modificándolos.

Esto sin duda para los temas míticos. El Gilgamés, efectivamente, influyó en Grecia: sobre este tema remito no sólo a mi artículo a que vengo refiriéndome, sino también a otro sobre Estesícoro ${ }^{61}$. Y el tema de Prometeo y Pandora, tanto en Teogonía como en Trabajos y Días, presenta rasgos muy característicos respecto a la restante tradición griega, así como fórmulas que garantizan que Hesíodo deriva de poesia griega tradicional. Añádanse a las fórmulas prometeicas ya reseñadas

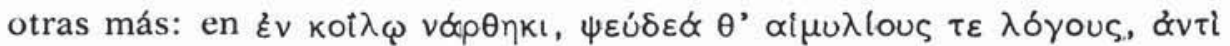

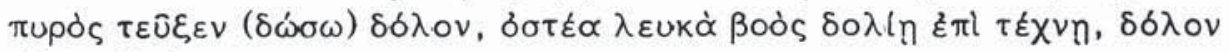

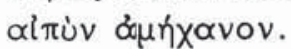

Ni más ni menos, hay que aceptar la existencia en Grecia de una literatura gnómica de tipo oral y tradicional. De máximas y preceptos está llena la literatura griega: Homero, la lírica, el teatro, etc. Pero existieron también, en fecha posterior a Hesíodo, colecciones de precep-

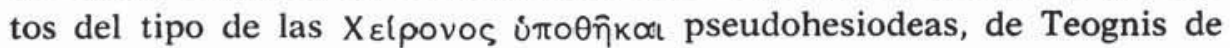
Mégara, de Focílides, el pseudo-Focílides, el pseudo-Pitágoras y luego, en prosa, el $A$ Nicocles, el Nicocles y el $A$ Demónico de Isócrates. Nótese que en estas obras están representados géneros que ya conocemos: la primera reúne consejos del educador al educando, la segunda del amante

60 Cf. Robert S. Falkowitz, "Discrimination and condensation of sacred categories: the Fable in early Mesopotamian Literature», en La Fable, Entretiens sur l'Antiquité Classique XXX, Vandœuvres-Genève 1984, pp. 1-24.

61 "Propuestas para una nueva edición e interpretación de Estesícoro", RMERITA 46,1978 , pp. $241-299$, sobre todo p. 266. 
al amigo más joven, el $A$ Nicocles de Isócrates contiene consejos al rey, el $A$ Demónico consejos a un joven. Pero existe también la parénesis "general", así la de Focílides, el pseudo-Focílides y el pseudo-Pitágoras. Están próximas una serie de obras de Demócrito. Hay que advertir que no se trata sólo de máximas o preceptos: también de símiles y fábulas, entre otros elementos.

No es de creer que esta literatura dependa sólo de Hesíodo, ni que esté influida directamente por el Oriente, ni que haya surgido espontáneamente. Se trata de diversos especímenes de un mismo género, anterior en Grecia a Hesíodo y que enlaza con los modelos orientales. Hay, eso sí, enlaces directos con la literatura esópica, que hemos estudiado en otro lugar ${ }^{62}$.

La prueba de lo que decimos se encuentra, una vez más, en la existencia de elementos formularios tradicionales en la poesía hesiódica, sobre todo en Trabajos y Dias. Aunque alguna fórmula es sin duda crea-

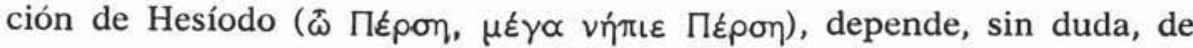
modelos antiguos (cf. el constante "hijo mío» en diversas colecciones de preceptos). Véanse otras, recogidas por Krafft: $\Phi^{\prime} \delta^{\prime} \varepsilon^{\prime} \rho \delta \varepsilon เ \nu$, « ${ }^{\prime} \lambda \lambda \circ \tau \varepsilon$

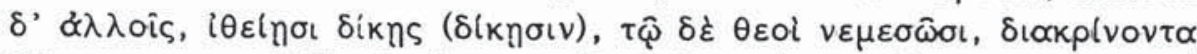

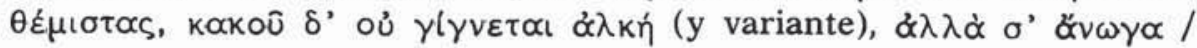

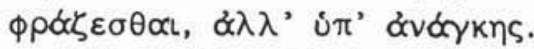

Pero mucho más importantes son los datos reunidos e interpretados por José Antonio Fernández Delgado en sus dos estudios sobre el tema, donde se pueden encontrar también referencias a la bibliografía anterior ${ }^{63}$. El primero de los dos trabajos referidos estudia las fórmulas hesiódicas con ớvíp, a veces halladas fuera de allí y en ocasiones emparentadas con otras de Homero. Más importante es el segundo trabajo, que recupera abundantes máximas formularias de Hesíodo: las más ante las cesuras pentemímeris o trocaica y muchas de ellas presentes también en autores como Teognis, Focílides, el pseudo-Focílides, etc. En estos autores existen, de otra parte, fórmulas independientes pero métricamente comparables; y unas y otras tienen, en ocasiones, precedentes en Homero. Nada tiene esto de extraño: también se encuentran en él ciertas fórmulas genealógicas.

Llamo la atención, sobre todo, sobre la lista de máximas formulares ${ }^{64}$ : las más en Trabajos y Días, otras en los demás autores reseñados.

62 Historia... I, p. 301 ss. y «The Life of Aesop and the origins of Greek Novel», Quaderni Urbinati, N. S. 1, 1979, pp. 93-112.

63 "Poesía oral gnómica en «Los Trabajos y los Días»: una muestra de su dicción formular», EMERITA 46, 1978, pp. 141-171 y "La poesía sapiencial griega y los orígenes del hexámetro", EMERITA 50, 1982, pp. 751-173.

i4 EMERITA 50, 1982, p. 169 ss. 


\section{La COMPOSICIÓN DE "TEOGonía» Y "TRABajos Y Dfas»}

\section{Teogonia.}

Hemos de imaginarnos a Hesíodo intentando componer (¿oralmente?, ¿dictando?) un poema cosmogónico-teogónico que supere a los que, inspirados en el Oriente asiático, circulaban por Grecia, recitados por aedos diversos. Contenían, evidentemente, versiones no siempre coincidentes, pero estaban emparentados temática y estilísticamente; también estaban emparentados con la tradición épica general, de la que representaban una variante. Eran, sin duda, poemas breves, con organización cronológica y concentrada. Incluían elementos de "épica divina» y tenían, posiblemente, un mínimo proemio invitando a la Musa a cantar; o bien eran recitados tras un himno a alguno de los dioses.

Sobre esta base, Hesíodo crea la "gran" teogonía, como Homero había creado antes la "gran" epopeya. Su gran invento es el proemio que anticipa el tema a cantar. Y su segundo invento es la ampliación de los elementos genealógicos y épicos para dar una imagen de la totalidad del mundo divino: el cosmos todo, los dioses y monstruos primigenios, los que para nosotros son principios abstractos, Zeus y los Olímpicos, los héroes hijos de Zeus. Todo va a tender, en efecto, hacia Zeus y su gloria: ésta es, sin duda, la tercera innovación. La mayor.

Para lograr esto Hesíodo tendrá un segundo modelo, Homero, al que sin duda recitaba como aedo que era: sobre todo la Ilíada, con su técnica de los anticipos y los anillos, sus digresiones, su tensión creciente que recobra cada vez más, y al final ya no pierde, el hilo central argumental. Éste aparece en islas cada vez más compactas, flotando entre el fondo de la leyenda heroica que no se quería, tampoco, olvidar. Y deja paso, al final, a un anticlímax en que decrece la tensión.

Otros modelos los encontraba en la poesía genealógica que circulaba por Grecia y, concretamente, por Beocia y que seguía en general la lengua y el estilo homéricos, pero presentaba rasgos propios y un sistema formulario en parte independiente. Otro todavía en diversos poemas de épica "divina". Con todo ello a la mano, podía ponerse a su tarea de crear un nuevo poema teogónico más amplio y ambicioso que los que circulaban en su tiempo.

Ciertamente, su tarea era difícil. Tenía que unir su religión de Zeus con mitos crudos que no podía tocar: aunque podía elegir entre las diversas versiones. Tenía que unificar dioses muy diferentes, así como tradiciones partogenéticas y del dios que engendra sin ayuda de mujer 
con otras matrilineares y patrilineares. Su guía era la cronología, pero las ramas laterales le obligaban a dejarla de lado durante largos trechos; luego tenía que recobrar la línea central Urano-Crono-Zeus. Los incestos también le hacían desviarse con saltos atrás. Y los momentos épicos, los puntos culminantes del mito de la Sucesión, ofrecían problemas a la composición, así como los excursos sobre divinidades o mitos importantes que no quería dejar de lado.

En términos generales es claro que en la Teogonía se sigue el hilo cronológico, como en los poemas orientales. Pero al querer el poeta presentar un cuadro total, por fuerza ha de detener en ocasiones el relato cronológico para atender a las ramas laterales: hay, pues, interrupciones y dioses "coetáneos" que son presentados a continuación unos de otros o incluso se retrocede en el tiempo para "repescar" una rama. Cuando se trata, como es frecuente, de uniones incestuosas (madre/hijo, abuela/nieto, etc.), dioses ya mencionados vuelven a aparecer. Otras veces hay anticipos: menciones de Zeus que presagian su futura gloria, por ejemplo. Hay otras detenciones todavía, como la descripción del Tártaro, de carácter diríamos que «local»: se describe una parte del mundo antes olvidada.

El panorama es, pues, mucho más complicado que en los poemas orientales que mejor conocemos, a saber, El reinado de los Cielos y el Enuma Elish, donde domina casi sin rival el principio cronológico. Ello concuerda con el hecho de que el contenido es también más complicado y, por tanto, más difícil de exponer.

Hesíodo ha tratado de facilitar su tarea organizando su poema mediante una serie de unidades que se siguen y que, a su vez, se fragmen$\tan$ en subunidades internas. Son, tras los dos proemios, fundametalmente cuatro:

I. Versos 136-210: del Caos inicial a la castración de Urano por Crono y el nacimiento de Afrodita. Es todo ello un relato (o una serie de relatos), es decir, un elemento $b$ fragmentado en varios: relatos genealógicos que culminan con el mito de la castración de Urano, rematado por una nueva serie genealógica: los descendientes de la sangre de Urano y de sus partes sexuales. Falta el elemento $a$ : evidentemente, es inútil tras los proemios (igual vimos que era el caso en Trabajos y Días). Pero hay un elemento $c$ o epílogo (igual que en los mitos y la fábula de dicha obra): son los versos 207-210 en que son presentados los reproches de Urano contra sus hijos los Titanes y se anticipa el castigo que recibirán por sus desafueros. Se apunta, pues, a la continuación de la historia y al triunfo de Zeus. 
II. Versos 211-336. Es en realidad un apéndice, porque la continuación de la historia habrá de esperar al elemento III. Así como I se refiere fundamentalmente a los hijos de Gea (de ella sola o con Urano), III va a ocuparse de los hijos de Urano: el principio va a cambiarse, y ello se anticipa al final de I con el nacimiento de Afrodita, hija solamente de Urano. Pues bien, II describe en forma yuxtapositiva, sin prólogo ni epílogo, los elementos ajenos a ese esquema. O sea, en primer lugar la rama lateral nacida de Caos a través de su hija la Noche (211232); en segundo lugar, los descendientes de Gea por la línea de Ponto y la de Océano: a veces por nacimiento espontáneo, a veces uniéndose estos dioses con la propia Gea, a veces entre sí. En todo caso, Gea está en el centro. Urano no interviene sino muy secundariamente (Océano que se une a Gea para dar nacimiento a Doris, es hijo de la propia Gea y Urano). Antes de entrarse en la sección III, la de los Uránidas, se completan estas complicadas genealogías. Al final hay varios mitos (Gerión, la Hidra, el león de Nemea) que permiten alusiones a Heracles, o sea, en definitiva, a la gloria de Zeus.

III. Versos 337-885: los Uránidas. Se enlaza con I, retrocediéndose en el tiempo (II llega a la generación IX, aquí estamos en la III, con los Titanes y demás descendientes de Urano). Es un complicado relato yuxtapositivo, que concluye en una serie de mitos y en un epílogo 881885: se insiste en la derrota de los Titanes y en la victoria de Zeus, los dioses otorgan el reino a Zeus por instigación de Gea. El anillo se cierra. Ahora bien, hay que notar cómo es la organización interna del relato: se cuentan en un orden más o menos convencional las uniones y descendencia de los distintos Uránidas, dejando para el final a Hécate (con un himno en que se glorifica también a Zeus) y a la descendencia de Rea y Crono, que culmina en Zeus. Todo ello lleva a una serie de mitos de Zeus: el de su nacimiento, su liberación de los Cíclopes, su triunfo sobre Prometeo, la Titanomaquia. Una digresión describe el Tártaro, donde fueron arrojados los Titanes, y la gloria de Zeus vuelve a brillar luego en el episodio de su victoria sobre Tifeo.

IV. Versos 886-955. Se refieren a la descendencia de Zeus, unido a una serie de divinidades que representan las más veces el mundo humano y justo de Zeus (Metis, Temis, Mnemosyne, etc.). Todo concluye con la boda de Heracles, hijo de Zeus y Alcmena, con Hebe, la juventud: los últimos versos del pasaje, que celebran la gloria de Heracles ( $\propto$ feliz él, que cumpliendo una gran hazaña entre los inmortales vive sin dolor ni vejez de por siempre») pueden considerarse como epílogo del poema

LIV, $1.0^{\circ}-3$ 
todo ${ }^{65}$. Si es cierto que éste es su antiguo final, como arriba hemos aceptado.

Después de este esquema, que habría que completar en el detalle, las diferencias entre nuestra Teogonía hesiódica y sus precedentes orientales son más claras que nunca. Y no sólo por lo dicho hasta aquí. La obra no es ya pura épica: la épica del Mito de la Sucesión y otra más se ha colocado en los momentos culminantes, que marcan la línea UranoCrono-Zeus. Fuera de esto, el esquema cronológico ha quedado envuelto en una red mitológica que comprende derivaciones laterales y da una imagen completa del mundo natural y divino. Eso sí, culmina en la gloria de Zeus, como el Enuma Elish en la de Marduk, El reinado de los Cielos en la de Tešub.

$\mathrm{Y}$ hay más todavía. A las cuatro generaciones de dioses de El reinado de los Cielos, el Enuma Elish (en realidad hay más, cuatro son las esenciales) y Filón de Biblos responden otras cuatro: bien que contando a Gea, que no es destronada, pero queda relegada en un momento dado. Ahora bien, Gea hace intervenir un principio femenino que en los otros poemas sólo interviene en el nacimiento de Marduk y de Zeus Demaro: Tešub nace de Kumarbi, fecundado por el semen de Anu. En el poema griego, esto halla eco en el nacimiento de Afrodita del sexo de Urano y en el de Atenea de Zeus; pero Crono nace de la unión de Urano y Gea, Zeus de la de Crono y Rea, que es una nueva diosa Tierra.

Hay un cambio de orientación fundamental. La versión que sigue Hesíodo está centrada, tras el momento del Caos, en el tema de la tierra madre, la gran diosa. Ella sola tiene hijos y luego tiene otros más en unión de Urano, entre ellos Crono; luego, en la sección II, continúa en pleno proceso creador, independientemente de Urano; y en III vuelve a intervenir en la línea principal, en la figura de Rea (Gea vuelve a aparecer como madre de Tifeo). Hay que pensar en las grandes diosas madres asiáticas, tales Cibebe o diversas diosas indias. Va unido esto al tema de la separación de Tierra y Cielo, tema muy difundido y que en Hesíodo se nos presenta como la castración de Urano. Pero no será de su solo semen del que vendrá la descendencia, sino de su progenio con Gea.

La sección I de Teogonía es muy interesante. Primero está el Caos, una especie de recipiente donde transcurre el proceso cósmico ${ }^{66}$ y luego están Gea, Eros y Tártaro, atetizado con frecuencia. Se supone que Gea

65 Cf. Northrup, art. cit., p. 9. Heracles es un héroe favorito del Hesíodo de las Eeas y en él culmina la gloria de su padre Zeus.

to Cf. John Bussanich, "A theoretical interpretation of Hesiod's Chaos", CPh 78 1983, pp. 212-219. 
es hija de Caos y que Eros, influjo de otras cosmogonías, simboliza todo el proceso sexual que luego va a tener lugar; de otra parte, lanza un primer hilo al mando divino y humano, hilo que será recogido como final de anillo en 201 ss., mito del nacimiento de Afrodita que cierra la sección. En el primer momento, no sexual y puramente cósmico, ya están anunciados el sexo y la humanidad. Éste será un procedimiento constante.

Todo va a centrarse en Gea en esta sección, según hemos dicho. Pero previamente hay una desviación lateral para hablar de otros dos hijos de Caos, Erebo y Noche, y su descendencia. Nótese que son posteriores a Gea y hasta a Eros, mientras que Océano y Tetis serán posteriores todavía: los principios esenciales de otras cosmogonías se subordinan aquí a Caos y Gea. Se subordina incluso Urano que, aunque esposo de Gea, es su hijo. Así, Hesíodo no nos presenta la pareja Cielo/Tierra como primordial. Primordial es sólo Gea, tras Caos. Produce hijos por sí misma. Urano es sólo uno de ellos. Claro que con él llega el principio sexual: pero Gea seguirá produciendo hijos bien sola, bien con padres diversos. Es la gran matriz universal.

La comparación con las figuras de la Gran Madre no es puramente metafórica. Gea (y Rea) es la Gran Madre, cuyo hijo y esposo está siempre subordinado. Es el caso de Atis, también castrado. Recuérdense los mitos indios: Kalī danzando sobre el cadáver de Siva y copulando con él, Parvatĩ (o un demonio que toma su forma) queriendo castrarlo. Por otra parte, los amplios episodios de Afrodita y Hécate nos presen tan una vez más el papel central de la diosa en el proceso de la vida.

Claro que no es Gea quien castra a Urano, sino, siguiendo el mito asiático, el hijo de éste, Crono. Pero lo hace ayudado por Gea, como igualmente, luego, Zeus se salva de Crono gracias a la astucia de Rea. La diosa madre tiene un esposo que es al tiempo su hijo o bien conspira con el hijo contra el padre. En realidad apenas lo necesita: Agdistis, origen de Cibebe, es andrógino e igual Cibebe a veces; lo son, unidos, Siva y su pareja. Gea procrea por sí misma y luego se une con sus hijos o nietos.

Este es el planteamiento hesiódico de los orígenes de los dioses. Nótese que Gea es al tiempo diosa y montaña: esconde a sus hijos en sus cavernas, que son su vientre. Desde un cierto momento, sin embargo, es junto con Urano madre de una serie de hijos: 126 ss. En la relación que se nos da aparecen los Cíclopes (no sabemos si hijos también de Urano o sólo de ella) y los Cienbrazos: ya hemos expuesto las objeciones a la antigüedad del pasaje. Pero es un nuevo hilo que Hesíodo tiende al futuro. Por primera vez, desde el proemio, se oye el nombre de Zeus 
(141), a quien los Cíclopes entregaron el rayo, su arma decisiva contra Tifeo. Los Cienbrazos están aquí para reaparecer en la Titanomaquia.

Sigue luego el mito de la castración, narrado en un estilo puramente homérico: tras la interrupción, sigue la historia de Crono (cf. el eco verbal 138-155), último de los descendientes de Urano: Hesíodo coloca al final al dios que va a ocupar en lo que sigue el papel central. Pero los mitos no van nunca solos, se acumulan. De la sangre de Urano nacen las Erinis y Gigantes, de su sexo Afrodita: ecos de los antiguos mitos del varón que se reproduce por sí sólo (recuérdense en Grecia los de los nacimientos de Atenea y Erictonio), utilizados para completar el cuadro genealógico y para presentarnos a Afrodita y Eros y cerrar, como decíamos, un anillo de referencias al mundo humano. Para anticipar, además, el papel central de los Uránidas en el resto de la historia. Sólo queda ya el epílogo 207-210, que apunta también a lo que sigue. Hay en todo ello una composición muy sabia.

Y sabia es también, como decíamos, la introducción de todo el apartado II, que se refiere a las ramas laterales, descartadas luego. Es un puro apéndice, una exposición acumulativa que nos lleva a la descenden. cia de la Noche (generación II, igual que Gea) y luego a la de Ponto (hijo de la sola Gea), con algunas conexiones con Océano, otro hijo de Gea. Nótese que se trata de la rama centrada en las aguas, degradada por Hesíodo (al contrario que Homero) a un papel secundario. Podríamos exponer en detalle los métodos expositivos. Se siguen ciertas líneas, para luego remontar en la cronología y tomar otras. Por ejemplo, de Ponto nace Nereo, luego de Ponto y Gea nacen Taumante y otros más, entonces se "repesca" a Nereo, de quien nacen las Nereidas y se vuelve a Taumante, etc. Se baja, en definitiva, de la generación III a la IX. Y en la última parte se recogen materiales arcaicos: nacimientos sin intervención de pareja (Crisaor y Pegaso de la sangre de Medusa), monstruos, incestos. Hesíodo no quiere olvidar nada, ofrece un cuadro completo. Pero apunta en varios mitos a Heracles, es decir, al fin mismo del poema. Y menciona a Zeus, v. 286.

Tras este apéndice puramente yuxtapositivo, viene la sección III, ya descrita. Lo fundamental es que aquí son los Uránidas el centro: ahora no es ya el principio femenino, sino el masculino el que domina. Es una innovación consciente, anticipada al final de I, como dijimos: con la victoria de Crono y el nacimiento de Afrodita. En realidad, Hesíodo vuelve al espíritu masculino de los mitos asiáticos de sucesión $\mathrm{y}$, al tiempo, al ambiente de su propia sociedad. Pero tiene que luchar con la tradición genealógica griega, predominantemente femenina, como decíamos. La solución es fácil: los nacimientos se dan siempre referidos a 
la madre, acompañada de los participios que sabemos. El mundo de la religión de la Gran Madre y de las genealogías femeninas es desplazado, pero deja su huella.

De otra parte, también a Zeus ha habido referencias a lo largo de la sección: 339 (Styx sube al Olimpo, Zeus la honra), 412 (Zeus honra a Hécate, cf. 423,428 , con referencia al tiempo al mundo humano, honor a los reyes justos).

Y una vez más se usan las acumulaciones de mitos para señalar el final de la sección, ya lo hemos dicho: son mitos de Zeus, que recogen las alusiones anteriores. También una vez más un mito va seguido de un apéndice genealógico que deja paso a un segundo mito: tras el del nacimiento de Zeus, se habla del titán Japeto y su descendencia, entre ella Prometeo, sólo para narrar el mito de éste, que culmina una vez más en la gloria de Zeus. No entro en el detalle del análisis de esta sección, que continúa con la descripción del Tártaro -aparentemente casual, ligada al destino de los Titanes, pero en realidad buscada para completar la descripción del mundo- y el episodio de Tifeo. Sobre la coherencia de todo ello, véase el artículo ya citado de Mme. Said; y recuérdese, desde otro punto de vista, que este episodio equivale a otros de los poemas asiáticos en que culmina la gloria del nuevo dios.

La sección IV, con los hijos de Zeus, no hace sino completar esta imagen, aunque sea con un anticlímax. Al tiempo, a través de las esposas de Zeus y de sus hijos, se nos introduce en el mundo de lo humano, al que ya hemos hallado referencias oblicuas (Eros, los hijos de la Noche y otras abstracciones, Prometeo).

Así, en definitiva, el núcleo Cosmogonía-Mito de la Sucesión ha tomado un aspecto bien diferente de sus lejanos modelos asiáticos. La orientación es nueva, debido sin duda en parte a los modelos intermedios griegos, pero también a la elección del poeta. De otra parte, los elementos épicos y genealógicos que se han introducido, inspirados por la tradición griega, se han organizado sabiamente. Los mitos o, mejor, sus acumulaciones, marcan los puntos clave de la leyenda divina, al final de I y III (y en parte de II). Las genealogías amplifican y dan universalidad al viejo esquema. Para hacerlo todo compatible, Hesiodo ha de organizar el poema en unidades, aplazar su curso mediante relatos relativos a genealogías laterales, temperar el criterio cronológico con otros que hemos apuntado. Pero la línea central es clara y el poeta cuida de señalarla con anticipos y cierres del anillo. Los procedimientos son estrictamente homéricos.

La línea, en definitiva, es bien conocida. De un mundo centrado en la preeminencia del principio femenino se pasa al de la preeminencia 
del masculino. Ciertos mitos crudos heredados se mantienen, pero a veces pierden su lugar central para convertirse en fósiles. El principio de la pareja domina. Y dentro de él, se pasa de un mundo de dioses naturales, monstruos y abstracciones a veces repelentes, a un mundo divino humanizado. Zeus es su símbolo. No se trata apenas directamente la creación del hombre, pero la conexión entre el nuevo mundo divino de Zeus y la vida humana, queda clara.

Así, pensamos, el hecho de que Hesíodo conserve las viejas tradiciones orientales nada estorba a su originalidad. Las ha dotado de nuevo sentido, al tiempo que de una nueva forma. El conocimiento de los modelos remotos ayuda a mejor comprender este sentido y esta forma. Van de otra parte unidos.

\section{Trabajos y Dias.}

Vamos a ser más breves sobre Trabajos y Dias que comenzó siendo, según decimos, una especie de complemento de Teogonía, dedicada al mundo humano presidido por Zeus y su justicia. La imita en la lengua, las fórmulas, los temas. En realidad, el comienzo no es más que una reelaboración de temas de la Teogonía: un proemio que es un resumen de los de ésta y que anuncia el tema de la justicia de Zeus; tres relatos míticos de tipo cosmogónico, dos de ellos (el de las Erides y el de Prometeo-Pandora) reelaborando temas de la Teogonía. A partir de ahí, Hesíodo ha creado una obra parenética mucho más amplia y completa que las que circulaban por Grecia.

Pero Trabajos y Dias carece de la claridad de líneas que, pese a lo que pueda parecer, ofrece Teogonía. La simetría exigiría continuar el proemio con una colección de proverbios o preceptos dirigida a Perses. Ya hemos dicho por qué se introducen en medio los tres mitos y una fábula, sacada ésta de su contexto original en alguna colección de proverbios. Es para destacar el tema de Zeus, que en las colecciones de proverbios se dejaba insertar menos fácilmente. De otra parte, el mito de las Erides presenta ya el tema del trabajo, que se entrelazará estrechamente en lo que sigue al de la justicia, presentado en el proemio.

En realidad, Hesíodo, que también aquí ha querido ser completo y que depende de poesía gnómica griega tradicional, ha ido derivando de los preceptos "personales" a otros generales. Ha colocado los primeros (dirigidos a Perses o a los reyes) como elemento $c$ de algunos de los elementos míticos y fabulísticos mencionados y luego ha continuado con más series de proverbios o preceptos. Se refiere a Perses, a Zeus, al trabajo y a la justicia, derivando de unos a otros de estos 
motivos y volviendo atrás de cuando en cuando. Pero, evidentemente, todo esto no era bastante para él y ha añadido en forma puramente yuxtapositiva un calendario agrícola que apenas tiene ya relación con Perses ni con Zeus y una serie de consejos sobre la navegación que son creación suya para ofrecer un pendant a los trabajos del campo.

Hasta aquí Hesíodo ha procedido añadiendo unidades, como en Teogonía, sólo que carecía de un principio cronológico para ordenarlas. Seguía el de añadir, simplemente, lo que consideraba necesario. Primero vienen los mitos y las fábulas (11-285), sobre esquemas $b-c$ o $a-b-c$, según dijimos. Su secuencia es en cierto modo lógica. El mito de las Erides ( $\sin a$, innecesario tras el proemio, y con un $c$ parenético) es seguido por el de Prometeo mediante un simple yớp "porquen: va a explicar la escasez de recursos de los hombres, en realidad todo lo que precede hace de elemento $a$. Contiene, ya lo hemos dicho, elementos $b$ y $c$. El tercer mito, el de las edades, contiene elementos $a, b$ y $c$, ya reseñados.

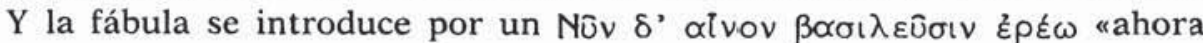
voy a contar una fábula a los reyes»: evidentemente, Hesíodo ha visto que era necesario, tras dirigirse a Perses, dirigirse a los reyes, ya mencionados en el elemento $c$ del mito de las Erides y en realidad aludidos en el proemio: una vez más vemos el procedimiento de las anticipaciones y los anillos. Pero el elemento $c$ de la fábula es complejo: contiene parénesis a Perses, luego a los reyes, luego a Perses todavía. Hace eco, sobre todo, al tema de la justicia, el central del proemio.

Sigue a continuación la exhortación a Perses unida al tema de los dos caminos (286-292) y una serie de máximas (293-382) que vuelven al tema del trabajo, unido al del Respeto (At $\delta \omega \varsigma$ ), la Riqueza o Felicidad $(\sigma \lambda \beta \circ \varsigma)$, la Justicia y Zeus. El primer pasaje puede interpretarse como un suplemento al elemento $c$ de la fábula, pero en realidad es una unidad con lo que sigue. Podemos tomar, pues, la exhortación sobre los dos caminos como $a$, siendo el centro $b$ la serie de máximas 286-292; un final $c$ insiste en el tema del trabajo ( $\omega \delta$ ' $\tilde{\varepsilon} \rho \delta \varepsilon เ \nu$, $k \propto l$ है $\rho \gamma o v$ $\varepsilon \pi^{\prime} \varepsilon^{\prime} \rho \gamma \omega \varepsilon^{2} \rho \gamma \alpha\langle\zeta \zeta \sigma \theta \propto a)$. El total es, evidentemente, un suplemento centrado en el trabajo, que sin duda Hesíodo ha considerado insuficientemente tomado en cuenta. Le ha dado una estructura ternaria y ha seleccionado o innovado el contenido parenético.

Un segundo suplemento es el calendario agrícola relativo al trabajo, pero concretamente al del campo. No entro en su detalle: es una composición en anillo que empieza y termina por el tema de la arada en Otoño. Aquí Hesíodo podía usar un principio cronológico, aunque utiliza la alternancia de éste y los relatos sobre el invierno y el otoño para lograr, como en Teogonía, una articulación más a su gusto. $\mathrm{Y}$ otro su- 
plemento es, a todas luces, el pasaje sobre los trabajos de la navegación (618-694). Lo ha organizado con un proemio $a$ en que introduce un sello con elementos biográficos y un centro $b$; el cierre $c$ consiste en dos máximas sobre la medida y la oportunidad. M. L. West ${ }^{67}$ ha propuesto, sobre ciertos precedentes, que el calendario y los trabajos de la navegación son añadidos al plan original. Esto es, sin duda, correcto. Pero también debe ser un suplemento la serie de máximas de que acabamos de hablar y, desde luego, todo lo que sigue hasta el final.

Es, pues, un procedimiento acumulativo, con todos los hilos hacia atrás y hacia delante que se quieran, con la búsqueda siempre de complementar lo no dicho, el que aquí sigue Hesíodo. Sólo de lejos se sigue la sabiduría compositiva de Teogonía al hilvanar los diversos géneros parenéticos existentes en Grecia, por más que yuxtaponga unidades con una cierta unidad de contenido y con tendencia a la estructura ternaria.

Hemos visto cómo, según va añadiendo elementos, el poeta va perdiendo en cierto modo la intención original, al contrario de lo que pasa en Teogonía. Y más todavía cuando añade la nueva serie de proverbios (695-764), puramente yuxtapositiva: un mero apéndice como el elemento II de Teogonía, sin huella de elementos $a$ y $c$. Y la de los "Días" (si son de Hesíodo). Conforme avanza el poema, Hesíodo es más esclavo de sus materiales, no sabe darles una nueva conformación, ni en el contenido ni en la forma, como había hecho antes en la Teogonía.

Francisco R. Adrados

67 "Is the works and Days an oral Poem?», cit., p. 65. 